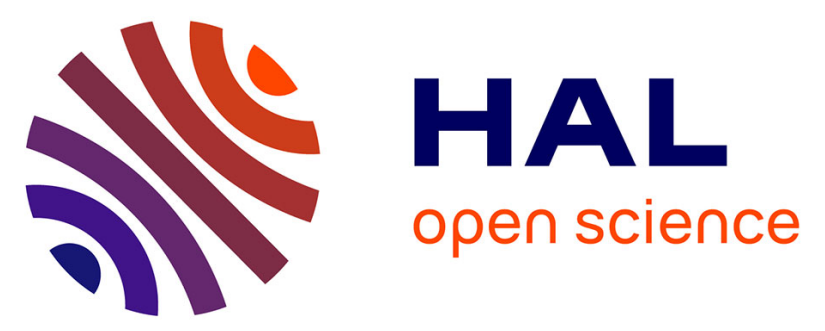

\title{
Multiscale investigation of the crystallization mechanisms and solute redistribution during annealing of a Fe64B24Y4Nb6Al0.4 metallic glass
}

Marie-Noëlle Avettand-Fènoël, Xavier Sauvage, Maya Marinova, Ahmed Addad

\section{To cite this version:}

Marie-Noëlle Avettand-Fènoël, Xavier Sauvage, Maya Marinova, Ahmed Addad. Multiscale investigation of the crystallization mechanisms and solute redistribution during annealing of a Fe64B24Y4Nb6Al0.4 metallic glass. Journal of Alloys and Compounds, 2021, Journal of Alloys and Compounds, 887, pp.161264. 10.1016/j.jallcom.2021.161264 . hal-03330538

\section{HAL Id: hal-03330538 \\ https://hal.univ-lille.fr/hal-03330538}

Submitted on 4 Oct 2021

HAL is a multi-disciplinary open access archive for the deposit and dissemination of scientific research documents, whether they are published or not. The documents may come from teaching and research institutions in France or abroad, or from public or private research centers.
L'archive ouverte pluridisciplinaire HAL, est destinée au dépôt et à la diffusion de documents scientifiques de niveau recherche, publiés ou non, émanant des établissements d'enseignement et de recherche français ou étrangers, des laboratoires publics ou privés. 


\title{
Multiscale investigation of the crystallization mechanisms and solute redistribution during annealing of a $\mathrm{Fe}_{64} \mathrm{~B}_{24} \mathrm{Y}_{4} \mathrm{Nb}_{6} \mathrm{Al}_{0.4}$ metallic glass.
}

\author{
M.-N. Avettand-Fènoël ${ }^{1 *}$, X. Sauvage ${ }^{2}$, M. Marinova ${ }^{3}$, A. Addad ${ }^{1}$ \\ ${ }^{1}$ Univ. Lille, CNRS, INRAE, Centrale Lille, UMR 8207, UMET - Unité Matériaux Et \\ Transformations, F-59000, Lille, France \\ ${ }^{2}$ Groupe de Physique des Matériaux, Normandie University, UNIROUEN, INSA Rouen, \\ CNRS, Rouen 76000, France \\ ${ }^{3}$ Univ. Lille, CNRS, INRAE, Centrale Lille, Univ. Artois, FR 2638, IMEC - Institut Michel- \\ Eugène Chevreul, F-59000, Lille, France \\ * corresponding author: Marie-Noelle.Avettand-Fenoel@univ-lille.fr
}

\section{Journal of Alloys and Compounds 887 (2021) 161264 \\ https://doi.org/10.1016/j.jallcom.2021.161264}

\begin{abstract}
The mechanisms and the sequence of crystallization of a $\mathrm{Fe}_{64} \mathrm{~B}_{24} \mathrm{Y}_{4} \mathrm{Nb}_{6} \mathrm{Al}_{0.4}$ metallic glass were investigated experimentally. To this end, the microstructure of the metallic glass after interrupted isothermal treatments at a temperature between glass transition and primary crystallization was studied by complementary techniques, namely atom probe tomography, transmission electron microscopy and X-ray diffractometry. During the early stages of crystallization of the glass, some nanometric $(\mathrm{Fe}, \mathrm{Nb}) \mathrm{B}$ crystals nucleate first by rejecting $\mathrm{Y}$ at their interface, which hinders their growth. The $\mathrm{Fe}_{62} \mathrm{~B}_{14} \mathrm{Y}_{3}$ dendritic phase starts growing in a second step. Longer annealings lead to the development of chemical gradients in the amorphous matrix surrounding $\mathrm{Fe}_{62} \mathrm{~B}_{14} \mathrm{Y}_{3}$ crystals, which favors the nucleation of additional nanometric $(\mathrm{Fe}, \mathrm{Nb})_{2.4} \mathrm{~B}$ crystals.
\end{abstract}

Keywords: A. Fe based metallic glass; primary crystallization; atom probe tomography; D. transmission electron microscopy; D. X-ray diffractometry

\section{Introduction}

Fe based metallic glasses are widely used in various applications such as sensors, inductor cores or radio-frequency identification systems. They are relatively cheap to produce and they exhibit unique combination of mechanical, electric and magnetic properties (namely high mechanical strength, high electrical resistivity and high saturation magnetization) [1-2]. However, since these properties are connected to their amorphous structure, the thermal stability and especially the crystallization process upon annealing beyond the glass transition temperature is extremely important. It is well known that during primary crystallization, the partitioning of alloying elements plays a key role on both the nucleation and the growth mechanisms [3-4]. They are mainly controlled by the atomic mobility in the amorphous phase which could give rise to concentration gradients near crystal/amorphous interface boundaries.

We have recently shown that in the Fe based $\mathrm{Fe}_{64} \mathrm{~B}_{24} \mathrm{Y}_{4} \mathrm{Nb}_{6} \mathrm{Al}_{0.4}$ metallic glass, the crystallization process ends up with a complex multi-crystalline structure with various phases [5]. Detailed investigations carried out by electron diffraction at the peak onset of primary crystallization suggested that the first crystals to nucleate are $\mathrm{FeB}$ or $\mathrm{Fe}_{2} \mathrm{~B}$ [5]. The exact 
nature of these primary crystals in such Fe based metallic glasses is however still a controversial issue. Some authors have reported the $\mathrm{Fe}_{23} \mathrm{~B}_{6}$ phase [1,6-10], even in alloys with very similar compositions [6], while others suggest $\mathrm{Fe}_{62} \mathrm{~B}_{14} \mathrm{Y}_{3}$ [11], Fe bcc solid solution [7,9,10,12], $\mathrm{Fe}_{2} \mathrm{~B}, \mathrm{NbB}$ combined with $\mathrm{Fe}_{3} \mathrm{~B}$ [13] or at last $\mathrm{Fe}_{14} \mathrm{Y}_{2} \mathrm{~B}$ [14]. Slight changes of chemical composition can indeed modify the crystallization stages and kinetics as well as the crystals nature as exemplified in a $\mathrm{Fe}_{41} \mathrm{Co}_{7} \mathrm{Cr}_{15} \mathrm{Mo}_{14} \mathrm{Y}_{2} \mathrm{C}_{15} \mathrm{~B}_{6}$ metallic glass [15-16].

Thus, the present study aims at identifying for the first time the sequence of crystallization and the mechanisms of the early stages of primary crystallization in the $\mathrm{Fe}_{64} \mathrm{~B}_{24} \mathrm{Y}_{4} \mathrm{Nb}_{6} \mathrm{Al}_{0.4}$ metallic glass. Amorphous ribbons of $\mathrm{Fe}_{64} \mathrm{~B}_{24} \mathrm{Y}_{4} \mathrm{Nb}_{6} \mathrm{Al}_{0.4}$ were thus systematically investigated after short time annealings, down to the atomic scale. Experimental data were collected using X-ray diffractometry and a combination of advanced techniques, namely high resolution transmission electron microscopy and atom probe tomography. This latter technique has never been applied to the metallic glass of the present study and relatively scarcely to other kinds of Fe based metallic glasses $[\mathbf{3 , 1 4 , 1 5 1 7}]$ although it may provide critical information about the three dimensional redistribution of solute atoms during crystallization.

\section{Experimental procedure}

The $\mathrm{Fe}_{64} \mathrm{~B}_{24} \mathrm{Y}_{4} \mathrm{Nb}_{6} \mathrm{Al}_{0.4}$ master alloy was produced by arc melting from high purity metallic elements, under a high purity argon atmosphere. In order to remove residual oxygen, a piece of titanium was set next to the crucible containing the master alloy. The production of metallic glass began as soon as titanium was melt. The chemical homogeneity of the alloy was ensured by four re-meltings of the alloy. Quenched alloys with the $\mathrm{Fe}_{64} \mathrm{~B}_{24} \mathrm{Y}_{4} \mathrm{Nb}_{6} \mathrm{Al}_{0.4}$ stoichiometry were then elaborated as melt spun ribbons. The $2 \mathrm{~mm}$ wide, $50 \mu \mathrm{m}$ thick and 30 $\mathrm{mm}$ long ribbons were prepared by single-roller melt spinning on a $\mathrm{Cu}$ rotating wheel.

The measured chemical composition of the metallic glass is given in Table 1. The $\mathrm{C}$, $\mathrm{N}$ and $\mathrm{O}$ contents were measured by LECO, while the $\mathrm{B}, \mathrm{Nb}$ and $\mathrm{Y}$ amounts were evaluated after mineralization by Inductively Coupled Plasma - Atomic Emission Spectrometry (ICPAES). The Fe content was finally estimated doing the balance.

Table 1: Measured chemical composition of the metallic glass (at.\%).

\begin{tabular}{ccccccccc}
\hline Element & $\mathbf{F e}$ & $\mathbf{B}$ & $\mathbf{N b}$ & $\mathbf{Y}$ & $\mathbf{C}$ & $\mathbf{B i}$ & $\mathbf{C r}$ \\
\hline at.\% & 64.305 & 24.600 & 6.037 & 4.346 & 0.113 & 0.002 & 0.010 \\
& \pm 0.009 & \pm 0.050 & \pm 0.005 & \pm 0.006 & \pm 0.042 & \pm 0.002 & \pm 0.009 \\
\hline $\mathbf{C u}$ & $\mathbf{M n}$ & $\mathbf{A l}$ & $\mathbf{P b}$ & $\mathbf{S i}$ & $\mathbf{A s}$ & $\mathbf{N}$ & $\mathbf{O}$ \\
\hline 0.033 & 0.031 & 0.429 & 0.077 & 0.015 & 0.004 & $<0.036$ & $<0.031$ \\
\pm 0.008 & \pm 0.009 & \pm 0.018 & \pm 0.002 & \pm 0.008 & \pm 0.007 & & & \\
\hline
\end{tabular}

According to differential scanning calorimetry (DSC) analysis (performed in a DSC404C Netzsch ${ }^{\mathrm{TM}}$ apparatus), the glass transition temperature $\left(\mathrm{T}_{\mathrm{g}}\right)$ of this metallic glass is $585 \pm 2^{\circ} \mathrm{C}$ and the onset temperature of primary crystallization $\left(\mathrm{T}_{\mathrm{x}}\right)$ is $677 \pm 2^{\circ} \mathrm{C}$ for a heating rate of $10{ }^{\circ} \mathrm{C} / \mathrm{min}$ (Fig. 1a and [5]). Three metallic glass ribbons were heated up to $667^{\circ} \mathrm{C}$ (between glass transition and primary crystallization onset temperatures) at $10^{\circ} \mathrm{C} / \mathrm{min}$ under argon in an $\mathrm{Al}_{2} \mathrm{O}_{3}$ crucible positioned in the DSC apparatus. Ribbons were kept at $667^{\circ} \mathrm{C}$ during 1,15 or $120 \mathrm{~min}$ and finally cooled down to room temperature at $-50^{\circ} \mathrm{C} / \mathrm{min}$. Corresponding DSC plots are exhibited in Fig. $1 \mathrm{~b}$. 

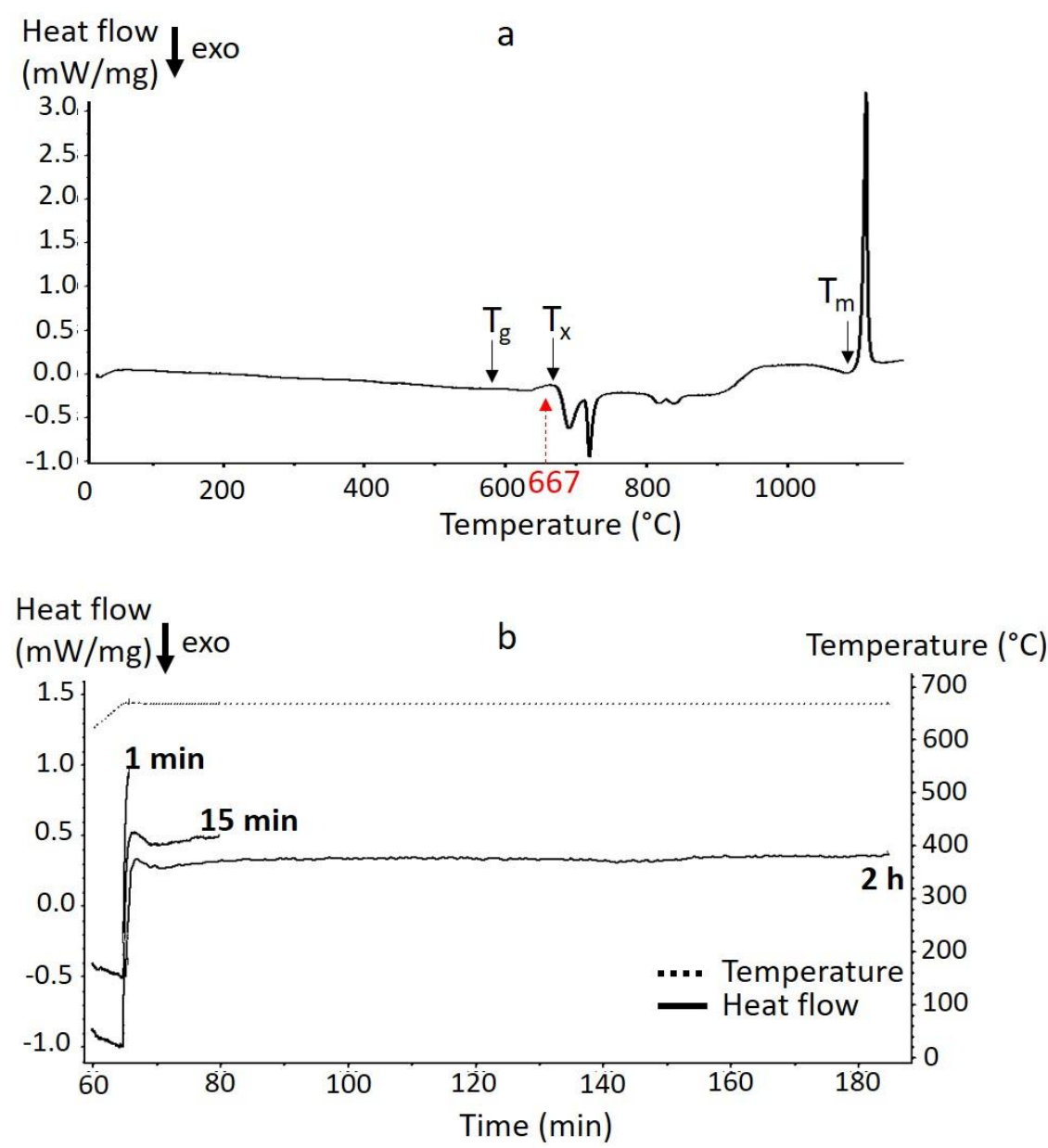

Figure 1: DSC signal of the metallic glass (a) at a heating rate of $10^{\circ} \mathrm{C} / \mathrm{min}$ and (b) at a heating rate of $10^{\circ} \mathrm{C} / \mathrm{min}$ and for holding times of $1 \mathrm{~min}, 15 \mathrm{~min}$ or $120 \mathrm{~min}$ at $667^{\circ} \mathrm{C}$.

Some X-ray diffraction (XRD) analyses of the metallic glasses after the 3 interrupted heat treatments at $667^{\circ} \mathrm{C}$ were performed with a $\mathrm{Cu}$ anticathod $\left(\lambda_{\mathrm{Cu}}=1.5406 \AA\right)$ and a BraggBrentano configuration on a $\mathrm{Si}$ low background support using a Rigaku Smartlab ${ }^{\text {TR }}$ diffractometer. These analyses carried out under air at room temperature enabled to identify the structure of the first crystals.

TEM samples were prepared by Focused Ionic Beam (FIB) with a FEI Strata DB $235^{\mathrm{TR}}$ instrument for the quenched state and a FEI Helios 600 Nanolab $^{\mathrm{TR}}$ for the heat-treated states. Thin foils were observed by high resolution scanning transmission electron microscopy (HR-S/TEM) using a ThermoFisher Titan Themis $300^{\mathrm{TR}}$ microscope, equipped with a probe aberration corrector and a monochromator, allowing spatial resolution of $70 \mathrm{pm}$ and energy resolution of $150 \mathrm{meV}$. Scanning TEM (STEM) observations were carried out with an accelerating voltage of $300 \mathrm{kV}$ with a spot size of about $500 \mathrm{pm}$, semi-convergence angle of $21 \mathrm{mrad}$ and probe current of approximately $100 \mathrm{pA}$. High angle annular dark field (HAADF) images were recorded with collection angles ranging from $50 \mathrm{mrad}$ to $200 \mathrm{mrad}$. The microscope has also a super-X windowless 4 quadrant SDD (silicon drift detector) detection system for the STEM-EDX (Scanning Transmission Electron Microscopy - Energy Dispersive Spectroscopy) mapping and several annular dark field detectors. These TEM data revealed the spatial distribution of the crystals at the sub-micrometric scale as well as the atomic arrangements and crystal lattices. 
Atom Probe Tomography (APT) samples were prepared by FIB, with a P-FIB Helios instrument. They were analyzed with a Cameca Leap $4000 \mathrm{HR}^{\mathrm{TR}}$ instrument at a temperature of $80 \mathrm{~K}$ with electric pulses (pulse repetition rate of $200 \mathrm{kHz}$, pulse fraction of 20\%). Threedimensional (3D) reconstructions were performed using IVAS Software and further data processing was done with the Gpm3dSoft Software. APT analyses provided information about the partitioning of alloying elements and the 3D morphology and the spatial distribution of the crystals.

\section{Results}

\subsection{As quenched metallic glass}

The quenched metallic glass exhibits the typical features of an amorphous state on parallel electron beam HRTEM images (Fig. 2a) and selected area electron diffraction pattern (Fig. 2b), and XRD data (Fig. 2c). Local measurements carried by APT (Tab. 2) revealed a composition close to the initial composition measured by ICP (Tab. 1). And two-dimensional chemical maps (Fig. 2d-e) clearly show that there are no significant chemical heterogeneities at the nanometer scale. The homogeneous distribution of elements was also confirmed by a statistical analysis (see supplementary material S1).
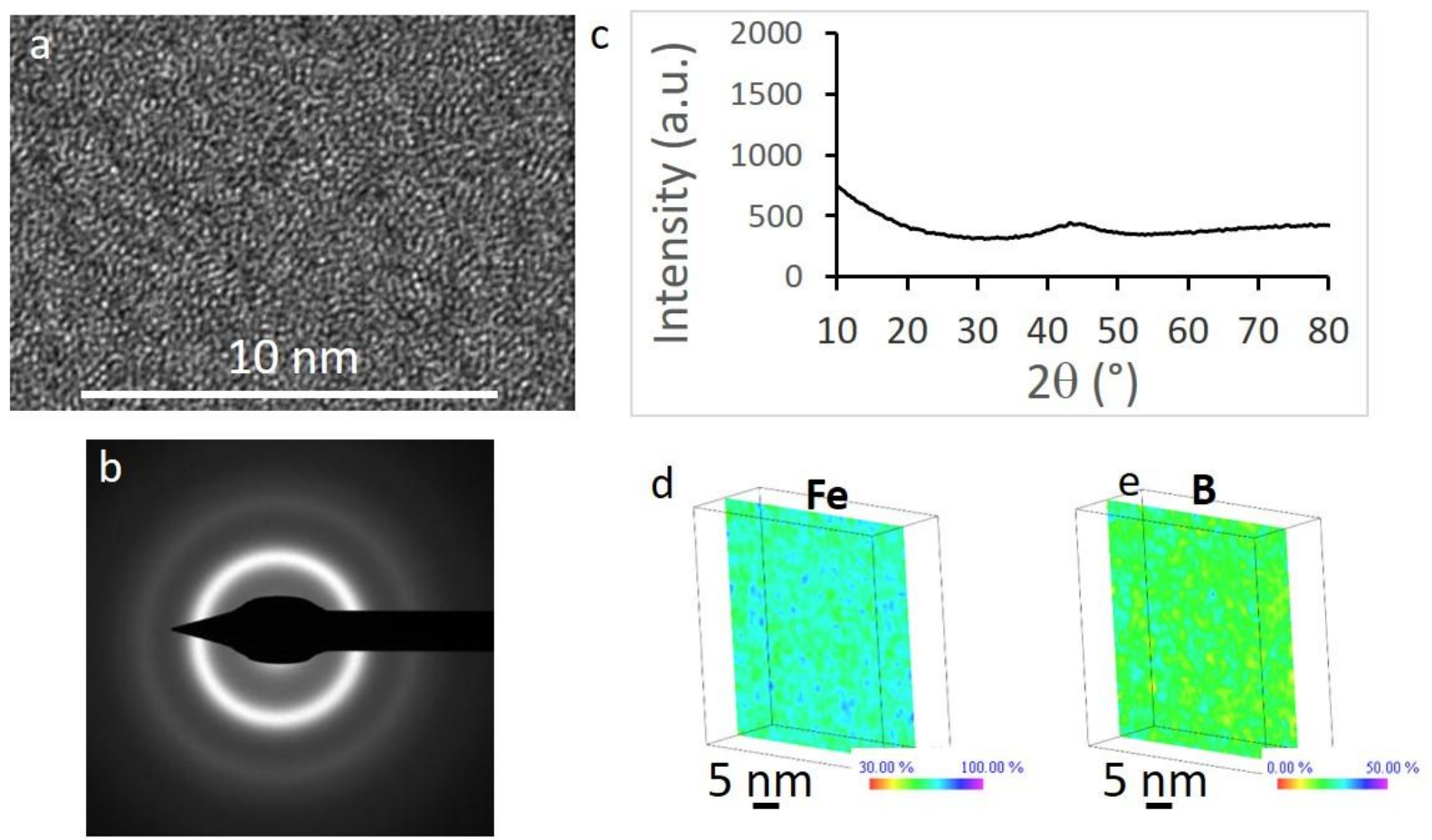

Figure 2: HRTEM image of the quenched metallic glass (a), selected area electron diffraction pattern showing continuous hallo rings typical of an amorphous structure (b), X-ray diffraction pattern of the quenched metallic glass (c), 2D Fe (d) and B (e) concentration maps computed with sampling volumes of $1 \times 1 \times 1 \mathrm{~nm}^{3}$ in a selection of $50 \times 50 \times 20 \mathrm{~nm}^{3}$ extracted from a reconstructed volume analyzed by APT in the quenched metallic glass.

Table 2: Chemical composition of the metallic glass measured by APT (at.\%).

\begin{tabular}{ccccccccc}
\hline Element & $\mathbf{F e}$ & $\mathbf{B}$ & $\mathbf{N b}$ & $\mathbf{Y}$ & $\mathbf{C}$ & $\mathbf{A l}$ & $\mathbf{N}$ & $\mathbf{M n}$ \\
\hline at.\% & 67.940 & 21.607 & 5.970 & 3.730 & 0.156 & 0.501 & 0.067 & 0.030 \\
& \pm 0.059 & \pm 0.052 & \pm 0.030 & \pm 0.024 & \pm 0.005 & \pm 0.009 & \pm 0.003 & \pm 0.002 \\
\hline
\end{tabular}




\subsection{Metallic glass after annealing}

\subsubsection{Crystallography of phases nucleated during isothermal holding at $667^{\circ} \mathrm{C}$}

Irrespective of the duration of the isothermal holding, the DSC analyses did not show any obvious exothermic signal corresponding to an eventual crystallization (Fig. 1b), which is very likely due to the lack of sensitivity of the equipment. Indeed, the XRD patterns with well-defined Bragg peaks corresponding to crystalline phases are clearly exhibited for the three annealing times at $667^{\circ} \mathrm{C}$ (Fig. 3). Peak indexation is complex due to many possible overlaps, but it seems to suggest the presence of $\mathrm{Fe}_{62} \mathrm{~B}_{14} \mathrm{Y}_{3}, \mathrm{FeB}, \mathrm{Fe}_{2} \mathrm{~B}$ and $\mathrm{Fe}_{3} \mathrm{~B}$ phases in the heat treated metallic glass (Fig. 3).

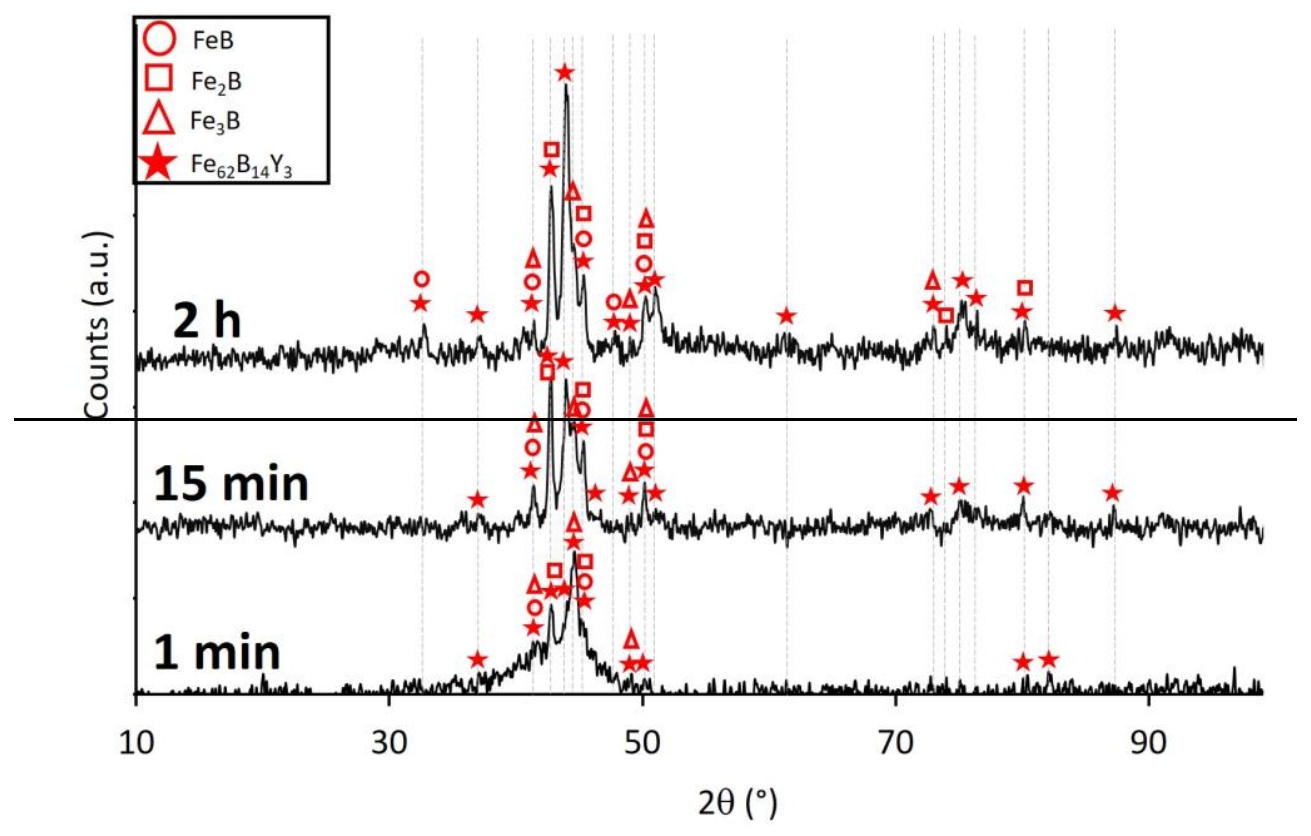




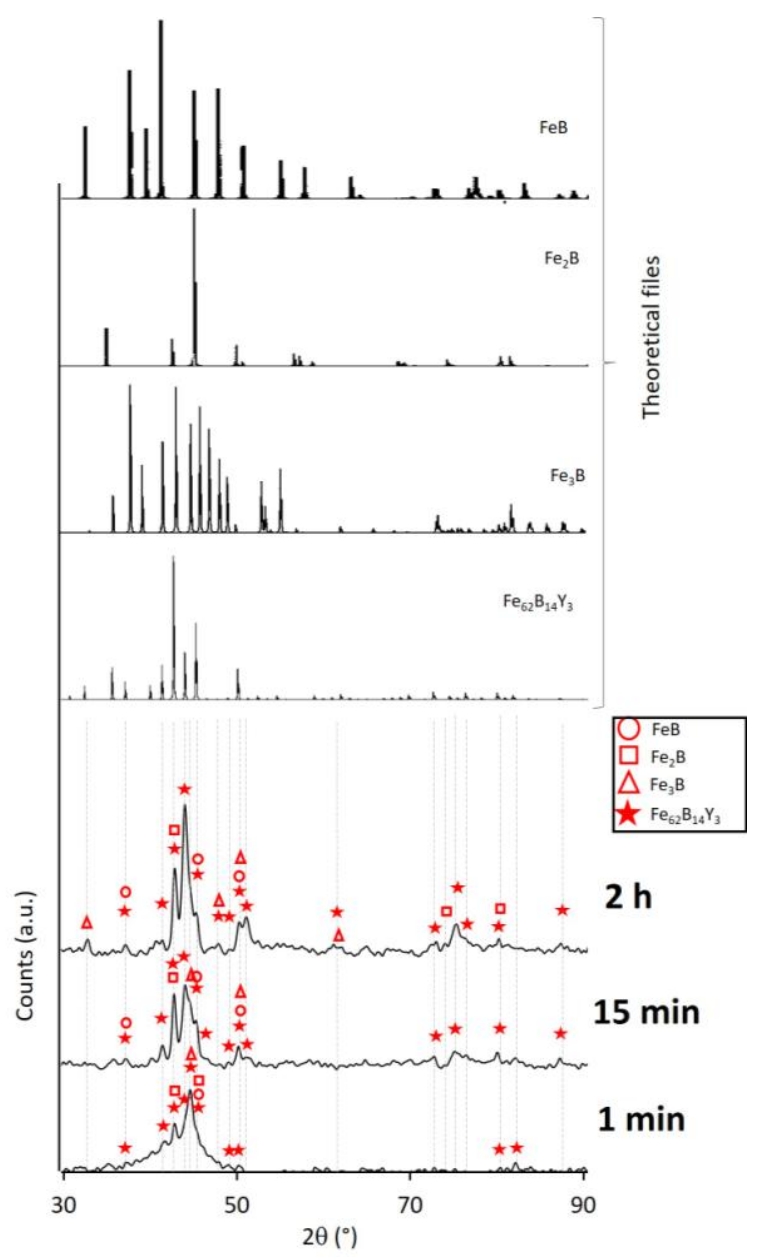

Fig 3a

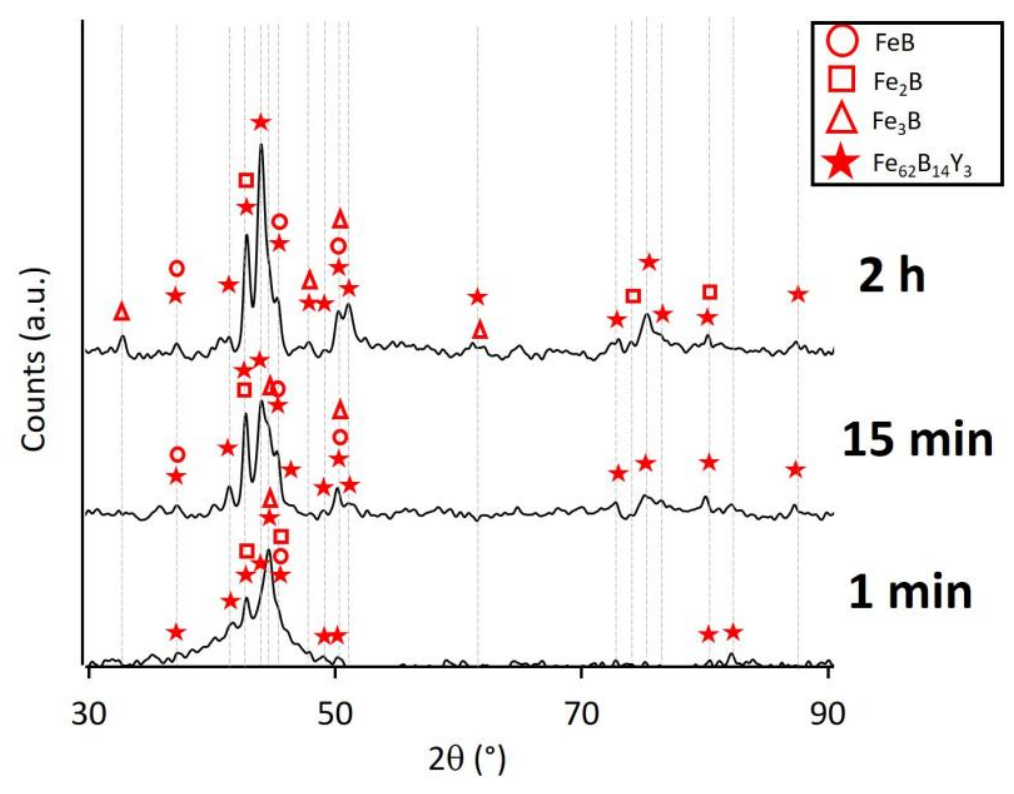

Fig 3b 


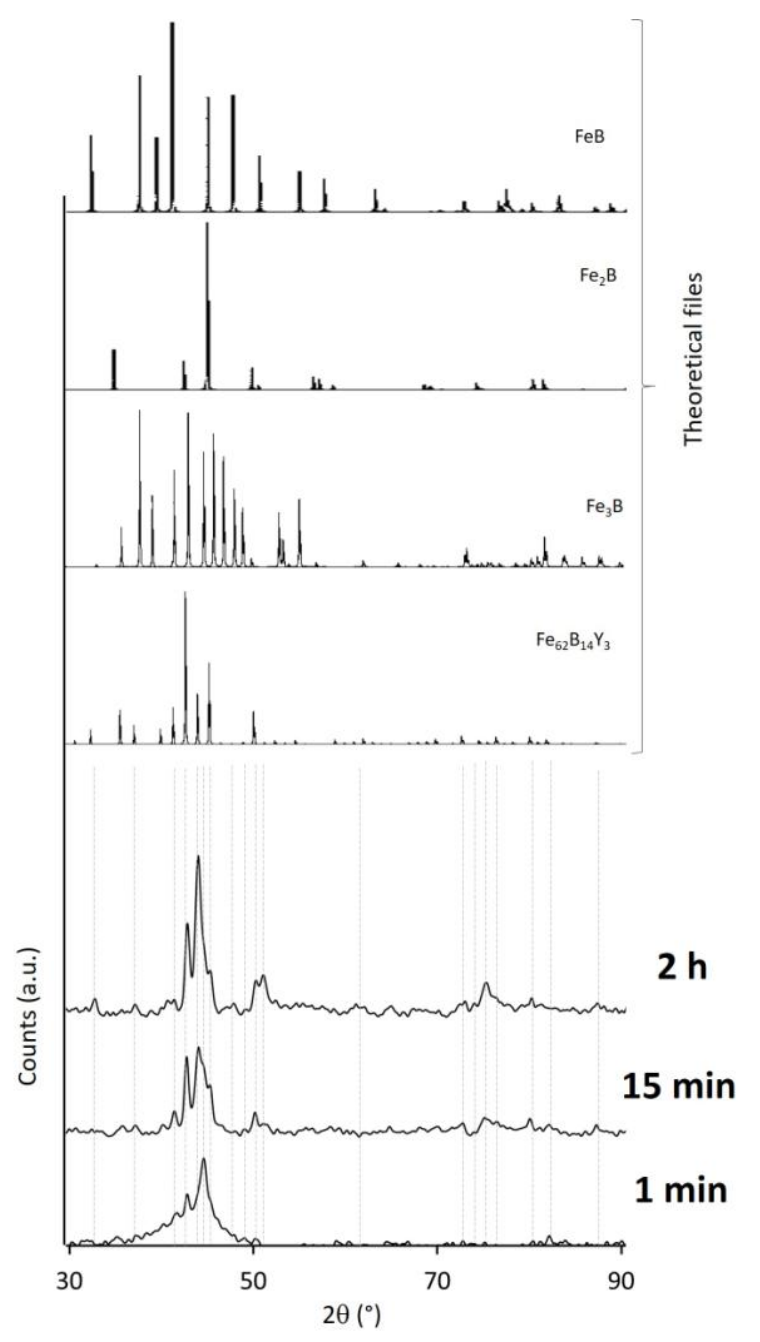

Fig 3c

Quelle figure garderais-tu : fig 3a, $3 \mathrm{~b}$ ou $3 \mathrm{c}$ ?

Figure 3: X-ray diffraction patterns of specimens after isothermal annealing at $667^{\circ} \mathrm{C}$ during 1 min, 15 min and $2 \mathrm{~h}$ and theoretical patterns of $\mathrm{FeB}, \mathrm{Fe}_{2} \mathrm{~B}, \mathrm{Fe}_{3} \mathrm{~B}$ and $\mathrm{Fe}_{62} \mathrm{~B}_{14} \mathrm{Y}_{3}$.

Besides, the sample annealed during $1 \mathrm{~min}$ at $667^{\circ} \mathrm{C}$ and thus corresponding to the early stage of crystallization is obviously not fully crystallized and since only very few peaks could be identified out of the background, it is impossible to conclude about the nature of the first crystals formed. Therefore, APT and HRTEM analyses were performed to shed light on the early stage of crystallization steps.

\subsubsection{Effect of isothermal annealing duration at $667^{\circ} \mathrm{C}$ on the $3 \mathrm{D}$ atomic distribution}

According to APT analyses, the isosurfaces drawn in Figs. 4a and 5a-c show that 3 phases could be detected after 1 and 15 min annealings at $667^{\circ} \mathrm{C}$, namely:

i) a phase that contains less than 75 at.\% Fe and less than 12 at.\% Nb. This is the major phase after $1 \mathrm{~min}$ in Fig. 4 and the left hand side phase in Fig. 5 (15 $\min )$. It will be referred as phase 1 in the following. 
ii) a phase with more than 75 at.\% Fe. This is the biggest "particle" (purple) surrounded by phase 1 in Fig. 4 (1 min) and the right hand side phase in Fig. 5 (15 min). It will be referred as phase 2 in the following.

iii) a phase containing more than 12 at.\% $\mathrm{Nb}$. This is the smallest "particle" (brown) surrounded by phase 1 in Fig. 4 (1 min) and surrounded by both phases 1 and 2 in Fig. 5 (15 min). It will be referred as phase 3 in the following.

APT quantitative analyses indicate that phase 1 exhibits a composition close to that of the matrix (Tab. 3). Its composition range is similar whatever the holding duration at $667^{\circ} \mathrm{C}$ but a slight Fe depletion and a B enrichment can be noted in phase 1 after the 15 min holding as compared to 1 min (Tab. 3).

The Fe rich phase 2 contains more $\mathrm{Y}$ but lower amounts of $\mathrm{B}, \mathrm{Nb}$ and $\mathrm{Al}$ than phase 1 (Tab. 3). Composition measured after 1 and $15 \mathrm{~min}$ at $667^{\circ} \mathrm{C}$ are quite similar with only a slight B enrichment after $15 \mathrm{~min}$ at $667^{\circ} \mathrm{C}$ (Tab. 3).

According to atomic analyses of the sample after $1 \mathrm{~min}$ at $667^{\circ} \mathrm{C}$, phase 3 is rich in $\mathrm{Fe}$, $\mathrm{Nb}$ and $\mathrm{B}$ (Figs. $4 \mathrm{~d}-\mathrm{g}$ and Tab. 3). After $15 \mathrm{~min}$ at $667^{\circ} \mathrm{C}$, two kinds of phase 3, more or less $\mathrm{Fe}$ rich but with a rather stable $\mathrm{Nb}$ content, are detected and their ranges of compositions are far narrower than after $1 \mathrm{~min}$ at $667^{\circ} \mathrm{C}$ (Tab. 3). In addition, it is worth noting that these $\mathrm{B}, \mathrm{Fe}$ and $\mathrm{Nb}$ bearing crystals are rather $\mathrm{Al}$ and $\mathrm{Y}$ free. Some enrichment in $\mathrm{Y}$ can be noticed at their surfaces (see Figs. 4e, 5g-h).

During the growth of the Fe-rich crystalline phase 2, some composition gradients develop in the amorphous matrix as revealed by concentration profiles (Figs. $4 \mathrm{f}$ and $5 \mathrm{~h}$ ). At the early stage of crystallization (shortest duration at $667^{\circ} \mathrm{C}$ ), a small $\mathrm{Nb}$ enrichment and a $\mathrm{Fe}$ depletion, both of approximately 3 at.\%, of the amorphous matrix are clearly exhibited over a distance of about $3 \mathrm{~nm}$ from the interface (Fig. 4f). After $15 \mathrm{~min}$ at $667^{\circ} \mathrm{C}$, these chemical gradients spread over much longer distances (about $40 \mathrm{~nm}$ ), and are more pronounced (about 10 at. $\%$ difference, see Fig. 5h).
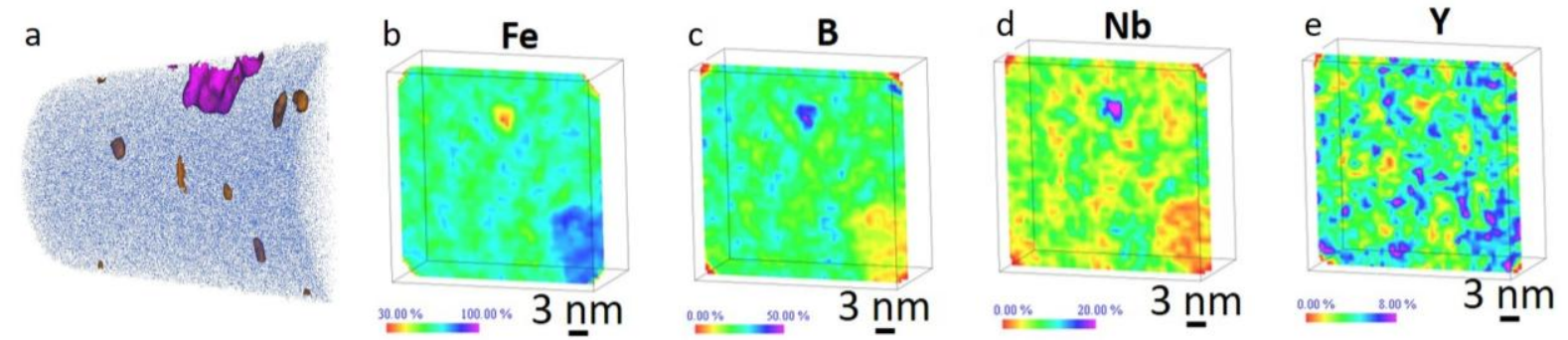

f

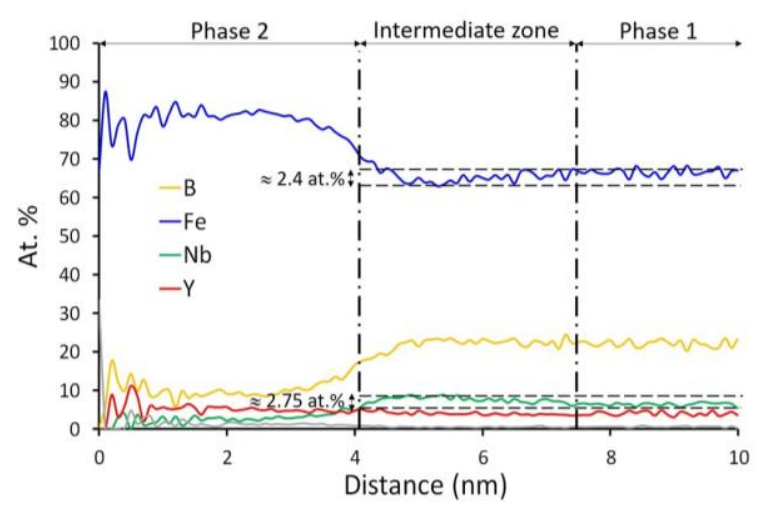


Figure 4: APT analyses on a $59 \times 68 \times 68 \mathrm{~nm}^{3}$ volume of a specimen after a 1 min holding treatment at $667^{\circ} \mathrm{C}: 75 \% \mathrm{Fe}-12 \% \mathrm{Nb} 3 \mathrm{D}$ isosurfaces (a) [Fe isosurface in purple and $\mathrm{Nb}$ isosurface in orange; blue dots are B atoms in the analyzed volume]. $\mathrm{Fe}(\mathrm{b}), \mathrm{B}(\mathrm{c}), \mathrm{Nb}(\mathrm{d})$ and $\mathrm{Y}$ (e) quantitative maps of a $40 \times 40 \times 20 \mathrm{~nm}^{3}$ volume. Erosion of phase 2 (f).
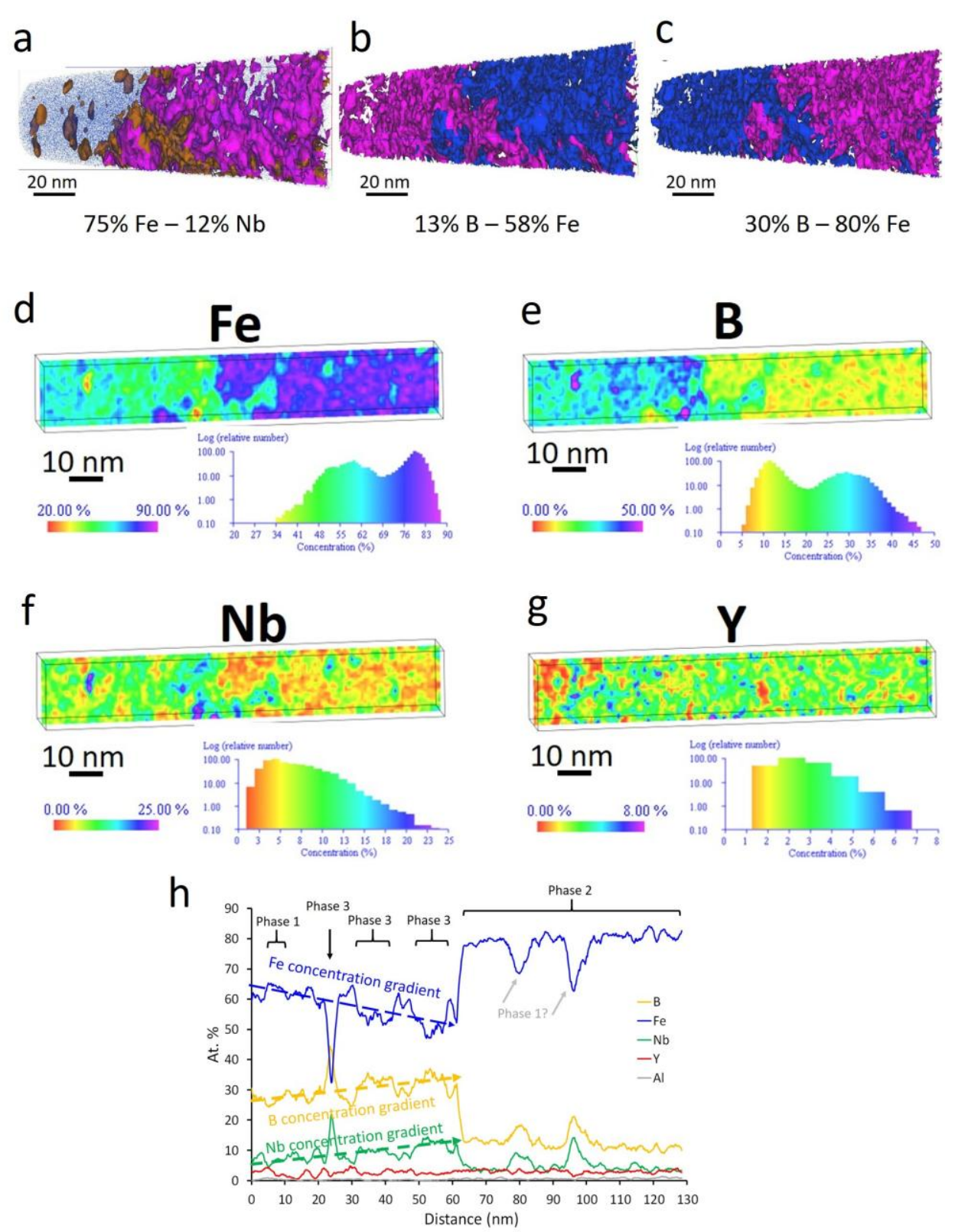

Figure 5: APT analyses of a specimen after a 15 min holding treatment at $667^{\circ} \mathrm{C}$ :

$75 \% \mathrm{Fe}-12 \% \mathrm{Nb}(\mathrm{a}), 13 \% \mathrm{~B}-58 \% \mathrm{Fe}$ (b) and $30 \% \mathrm{~B}-80 \% \mathrm{Fe}$ (c) 3D isosurfaces [B isosurface is in blue, $\mathrm{Fe}$ isosurface in purple and $\mathrm{Nb}$ isosurface in orange; Blue dots are $\mathrm{B}$ atoms in the analyzed volume]. Quantitative Fe (d), B (e), Nb (f), Y (g) maps of a $25 \times 25 \times 120$ $\mathrm{nm}^{3}$ volume of the specimen. Quantitative profile through phases 1, 2 and 3 (Each point of analysis corresponds to the information of a $5 \times 5 \times 2 \mathrm{~nm}^{3}$ volume of material) (h). 
Table 3: Chemical composition (at.\%) of the quenched metallic glass and of the phases vs. holding time at $667^{\circ} \mathrm{C}$. The contents of other detected elements $(\mathrm{C}, \mathrm{N}, \mathrm{Mn}, \mathrm{P}, \mathrm{Cr})$ are lower than 0.3 at. $\%$ and are not given. The total chemical compositions of analyzed volumes in heat treated states are given to show that they are similar to the quench state and thus fully representative.

\begin{tabular}{|c|c|c|c|c|c|c|}
\hline State & & $\mathrm{Fe}$ & $\mathrm{B}$ & $\mathrm{Nb}$ & $\mathrm{Y}$ & $\mathrm{Al}$ \\
\hline $\begin{array}{l}\text { Quenched } \\
\text { state }\end{array}$ & Matrix* & $67.94 \pm 0.06$ & $21.61 \pm 0.05$ & $5.97 \pm 0.03$ & $3.73 \pm 0.02$ & $0.50 \pm 0.01$ \\
\hline \multirow{4}{*}{$\begin{array}{c}1 \mathrm{~min} \\
\text { holding } \\
\text { time at } \\
667^{\circ} \mathrm{C}\end{array}$} & $\begin{array}{c}\text { Analyzed } \\
\text { volume*,** }\end{array}$ & $66.68 \pm 0.05$ & $22.32 \pm 0.05$ & $6.00 \pm 0.03$ & $3.97 \pm 0.02$ & $0.53 \pm 0.01$ \\
\hline & Phase 1 & $66.14 \pm 2.12$ & $22.04 \pm 1.85$ & $6.98 \pm 1.14$ & $3.96 \pm 0.87$ & $0.60 \pm 0.34$ \\
\hline & Phase 2 & $\begin{array}{l}82.43 \pm 1.52 \\
81.75 \pm 3.17\end{array}$ & $\begin{array}{l}8.52 \pm 1.11 \\
7.93 \pm 2.22\end{array}$ & $\begin{array}{l}2.51 \pm 0.62 \\
1.86 \pm 1.11\end{array}$ & $\begin{array}{l}5.09 \pm 0.88 \\
6.41 \pm 2.01\end{array}$ & $\begin{array}{l}1.11 \pm 0.42 \\
1.12 \pm 1.00\end{array}$ \\
\hline & Phase $3(=3 a)$ & $33.98 \pm 9.33$ & $44.66 \pm 9.79$ & $19.41 \pm 7.79$ & - & - \\
\hline \multirow{5}{*}{$\begin{array}{l}15 \mathrm{~min} \\
\text { holding } \\
\text { time at } \\
667^{\circ} \mathrm{C}\end{array}$} & $\begin{array}{c}\text { Analyzed } \\
\text { volume* }\end{array}$ & $70.92 \pm 0.03$ & $18.71 \pm 0.03$ & $6.48 \pm 0.02$ & $2.89 \pm 0.01$ & $0.54 \pm 0.01$ \\
\hline & Phase 1 & $64.91 \pm 2.48$ & $24.90 \pm 2.25$ & $5.13 \pm 1.14$ & $3.64 \pm 0.97$ & $0.67 \pm 0.42$ \\
\hline & Phase 2 & $81.46 \pm 1.93$ & $10.66 \pm 1.53$ & $3.53 \pm 0.91$ & $3.10 \pm 0.86$ & $0.68 \pm 0.41$ \\
\hline & Phase 3a & $32.29 \pm 3.12$ & $43.32 \pm 3.31$ & $21.94 \pm 2.76$ & $1.45 \pm 0.79$ & $0.33 \pm 0.38$ \\
\hline & Phase $3 b$ & $45.38 \pm 3.36$ & $28.84 \pm 3.06$ & $23.71 \pm 2.87$ & $1.59 \pm 0.84$ & - \\
\hline
\end{tabular}

* the use of different ribbons of metallic glass, but stemming from the same master alloy, for the quenched state and the annealing states after different durations may be the reason for the slightly different chemical composition of the analyzed volume after 15 minutes of annealing as compared to others.

** The spatial distribution, the size and the volume fraction of crystals undoubtedly govern the chemical composition of the amorphous matrix. It is believed that the measured chemical composition of the amorphous matrix is not significantly different after $1 \mathrm{~min}$ annealing because of the very low volume fraction of small crystallized particles.

\subsubsection{Size, morphology, spatial distribution and "identification" of crystals formed during isothermal holding at $667^{\circ} \mathrm{C}$}

Since APT analyses do not supply information about the crystalline structure of phases, HRTEM and electron diffraction analyses were performed to identify the 3 phases identified by APT and also to correlate with XRD data.

HRTEM indeed shows the presence of two kinds of crystals embedded in a glassy matrix (Fig. 6) whose volume decreases with an increase of the holding time at $667^{\circ} \mathrm{C}$ (Figs. $3,4,5,6 a-c)$.

First, some rather polygonal small crystals are detected by HRTEM (Fig. 6d-e). They have a size similar to particles of phase 3 detected by APT, ranging from 4 to $8 \mathrm{~nm}$ (Fig. 4 and Fig. 6d-e). Given its localization (Fig. 4), phase 3 seems to nucleate heterogeneously.

HRTEM analyses also prove the presence of bigger crystals (Fig. 6a-c,f-g) whose nucleation seems to be also heterogeneous (Fig. 6a). EDX analyses show that these crystals contain more $\mathrm{Fe}$ and less $\mathrm{Nb}$ than the matrix (Fig. 6h-1). The HAADF and the respective fast Fourier transforms (FFT) suggest that these crystals correspond to the $\mathrm{Fe}_{62} \mathrm{~B}_{14} \mathrm{Y}_{3}$ phase after 1 min, $15 \mathrm{~min}$ and $2 \mathrm{~h}$ holding at $667^{\circ} \mathrm{C}$ (Fig. $7 \mathrm{a}-\mathrm{g}$ ): experimental crystal lattice distances of the big crystals are consistent with those of $\mathrm{Fe}_{62} \mathrm{~B}_{14} \mathrm{Y}_{3}$ phase and the distances ratios and angles are characteristic of a body-centered cubic structure. After $1 \mathrm{~min}$ at $667^{\circ} \mathrm{C}$, these $50 \mathrm{~nm}$ sized crystals exhibit a cauliflowered morphology in 2 dimensions (Fig. 6a,f). Their surfacic density estimated by two dimensional TEM data, is close to 26 crystals per $\mu \mathrm{m}^{2}$ (Fig. 6a) with a 
spacing of about $160 \mathrm{~nm}$ between crystals. With an increase of the isothermal holding duration, the biggest crystals reach a size close to $100 \mathrm{~nm}$ after $15 \mathrm{~min}$ of holding (Fig. 6b and g) and are separated from each other by about $100 \mathrm{~nm}$. A prolongation of the isothermal holding up to $2 \mathrm{~h}$ generates biggest crystals (170 $\mathrm{nm}$ mean size) with a mean interspace of about $15 \mathrm{~nm}$ (Fig. 6c). After $15 \mathrm{~min}$ and $2 \mathrm{~h}$ at $667^{\circ} \mathrm{C}$, these crystals appear as polygonal agglomerates in 2 dimensions (Fig. 6b-c and g), which proves that they nucleate and grow in the matrix. Thus, there is a good agreement between APT and TEM data. It should be however noted that measured compositions do not exactly fit the theoretical stoichiometry of identified crystallographic structures. This specific point will be discussed in the following section.
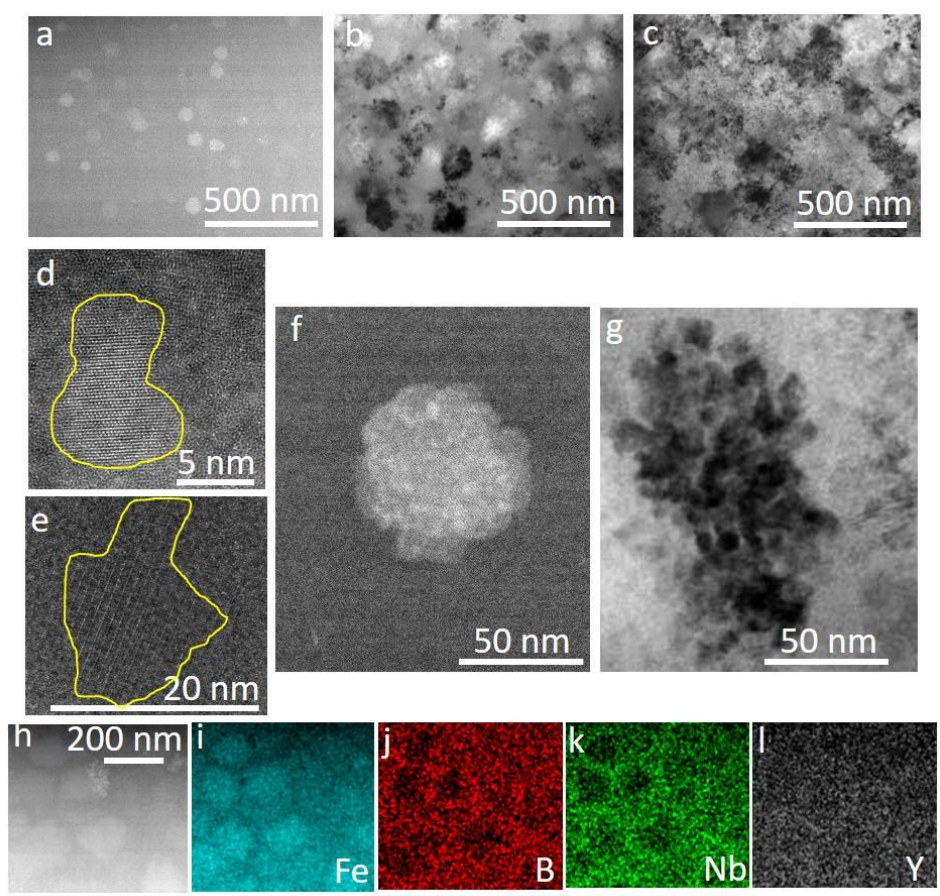

Figure 6: Sample after holding at $667^{\circ} \mathrm{C}$ for $1 \mathrm{~min}$ (a, d and f), $15 \mathrm{~min}(\mathrm{~b}$, e and g) and $2 \mathrm{~h}$ (c) (HAADF (d-f) and bright field, TEM (a-c,g)). Example of STEM-EDX mapping (i-l) and the corresponding HAADF image (h) of the sample annealed for 15 min where panels (i-l) are respectively $\mathrm{Fe}, \mathrm{B}, \mathrm{Nb}$ and $\mathrm{Y} \mathrm{X}$-ray maps. 

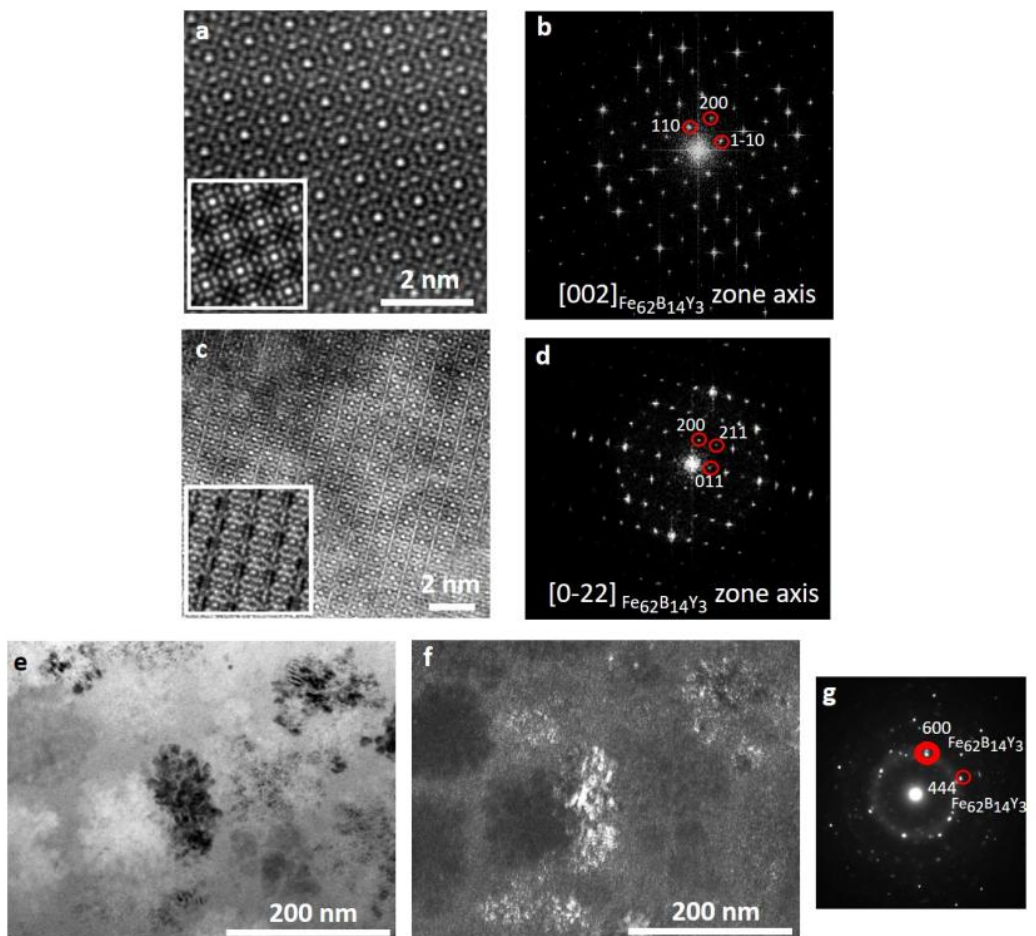

Figure 7: Lattice images of crystals detected in the amorphous phase: STEM-HAADF (a and c) and respective FFT ( $b$ and d) of the biggest crystals in samples after 1 min (a-b) and $2 \mathrm{~h}$ (cd) holding at $667^{\circ} \mathrm{C}$. They all have been attributed to $\mathrm{Fe}_{62} \mathrm{~B}_{14} \mathrm{Y}_{3}$ phase. The inserts in HAADF images are simulated HAADF of $\mathrm{Fe}_{62} \mathrm{~B}_{14} \mathrm{Y}_{3}$ structure (ICSD file 68327) with Dr. Probe software [1618] by considering a $40 \mathrm{~nm}$ thick sample and multislice model with 10 multislices per scan pixel and images of $124 \times 124$ pixels. TEM parallel beam bright field micrograph of sample after $15 \mathrm{~min}$ at $667^{\circ} \mathrm{C}$ (e), corresponding dark field image (f) obtained with the diffracted beam circled on the diffraction pattern $(\mathrm{g})$.

\section{Discussion}

\subsection{Nature of primary crystals}

Concerning the smallest crystals, according to Fig. 4-5 and Tab. 3 and by comparison with $\mathrm{Fe}, \mathrm{B}, \mathrm{Nb}$ bearing phases reported in literature (table $\mathrm{A}$ in appendix), phase $3 \mathrm{a}$ presents a stoichiometry close to $\mathrm{FeB}$, and phase $3 \mathrm{~b}$ a $\mathrm{Fe}_{2.4} \mathrm{~B}$ stoichiometry which is intermediate between $\mathrm{Fe}_{2} \mathrm{~B}$ and $\mathrm{Fe}_{3} \mathrm{~B}$. X-ray diffraction analyses seem to confirm the presence of $\mathrm{FeB}$, $\mathrm{Fe}_{2} \mathrm{~B}$ and $\mathrm{Fe}_{3} \mathrm{~B}$ (Fig. 3). Actually, in such structures, there would be a substitution of Fe atoms by $\mathrm{Nb}$ atoms since $\mathrm{Fe}$ and $\mathrm{Nb}$ exhibit similar atomic radii. The Goldschmidt radii of $\mathrm{Fe}, \mathrm{Nb}, \mathrm{B}$ and $\mathrm{Y}$ atoms are indeed $128 \mathrm{pm}, 147 \mathrm{pm}, 97 \mathrm{pm}$ and $181 \mathrm{pm}$ respectively [1719]. These results seem to confirm authors' previous results on the suspected formation of $\mathrm{FeB}$ and $\mathrm{Fe}_{2} \mathrm{~B}$ phases in such glasses during continuous heating up to $1400^{\circ} \mathrm{C}$ [5]. In addition, phase 3 ( $3 \mathrm{a}$ and $3 b$ ) is $\mathrm{Y}$ depleted (Tab. 3) and its nucleation leads to significant rejection of $\mathrm{Y}$ at interfaces (Figs. 4b-e, 5d-g). The resulting Y enrichment around phase 3 can be explained by thermodynamical considerations. $\mathrm{Nb}$ and $\mathrm{Y}$ are indeed repulsive (the heat of mixing for $\mathrm{Y}-\mathrm{Nb}$ is positive $(30 \mathrm{~kJ} / \mathrm{mol})[\mathbf{6 , 1 8 2 0}])$ while it is negative for $\mathrm{Y}-\mathrm{B}, \mathrm{Fe}-\mathrm{B}, \mathrm{Nb}-\mathrm{B}$ and $\mathrm{Fe}-\mathrm{Nb}$ systems (heat of mixing of -50 to $-35 \mathrm{~kJ} / \mathrm{mol},-26$ to $-16 \mathrm{~kJ} / \mathrm{mol},-39 \mathrm{~kJ} / \mathrm{mol}$ and $-16 \mathrm{~kJ} / \mathrm{mol}$, respectively $[\mathbf{2}, \mathbf{1 2}, \mathbf{1 9}, \mathbf{2 0 2 1}, \mathbf{2 2}])$. 
With regard to big crystals (Fig. 6a and f), lattice distances extracted from electron diffraction patterns seem to be typical of the $\mathrm{Fe}_{62} \mathrm{~B}_{14} \mathrm{Y}_{3}$ crystal structure (Fig. 7). This crystallographic structure was also revealed by XRD analyses (Fig. 3). $\mathrm{Fe}_{62} \mathrm{~B}_{14} \mathrm{Y}_{3}$ phase is a metastable body centered cubic structure, space group 229 with a lattice parameter of 12.36 Angströms [11,2123]. As shown on EDX maps (Fig. 6), these crystals are Fe rich, thus they correspond to phase 2 detected by APT (see Tab. 3) but surprisingly they do not exhibit the stoichiometry of $\mathrm{Fe}_{62} \mathrm{~B}_{14} \mathrm{Y}_{3}$. According to its atomic composition, phase 2 presents a deviation from stoichiometry of $\mathrm{Fe}_{62} \mathrm{~B}_{14} \mathrm{Y}_{3}$. Indeed, in the $\mathrm{Fe}_{62} \mathrm{~B}_{14} \mathrm{Y}_{3}$ phase, expected $\mathrm{Fe} / \mathrm{B}, \mathrm{Fe} / \mathrm{Y}$ and $\mathrm{B} / \mathrm{Y}$ ratios are 4.4, 20.6 and 4.7 respectively, while those extracted from APT data are $10 \pm 0.3$, $14.4 \pm 1.6$ and $1.45 \pm 0.25$ for $\mathrm{Fe} / \mathrm{B}, \mathrm{Fe} / \mathrm{Y}$ and $\mathrm{B} / \mathrm{Y}$, respectively (see table $\mathrm{A}$ in appendix). Thus the composition of phase 2 would be more consistent with stoichiometries close to $\mathrm{Fe}_{24} \mathrm{~B}_{2} \mathrm{Y}_{2}$ or $\mathrm{Fe}_{23} \mathrm{~B}_{3} \mathrm{Y}_{2}$ (see table $\mathrm{A}$ in appendix), which are metastable according to ab-initio calculations at $0 \mathrm{~K}$ in the $\mathrm{B}-\mathrm{Fe}-\mathrm{Y}$ system [2123]. $\mathrm{Fe}_{24} \mathrm{~B}_{2} \mathrm{Y}_{2}$ presents a tetragonal centered structure (space group 139) with lattice parameters: $a$ of 8.449 Angströms and $c$ of 4.869 Angströms, while $\mathrm{Fe}_{23} \mathrm{~B}_{3} \mathrm{Y}_{2}$ has a body centered cubic structure, space group 220 with a lattice parameter of 13.853 Angströms [21-2323-25]. But the special frequencies observed in the FFT patterns given in Fig. 7 do not correspond to any lattice distances indexed for those $\mathrm{Fe}_{24} \mathrm{~B}_{2} \mathrm{Y}_{2}$ and $\mathrm{Fe}_{23} \mathrm{~B}_{3} \mathrm{Y}_{2}$ phases.

It is worth noting that the compositions of primary crystals are rather consistent with $\mathrm{Fe}_{62} \mathrm{~B}_{14} \mathrm{Y}_{3}$ observed by De Mooij et al. in $\mathrm{Fe}_{124} \mathrm{~B}_{28} \mathrm{Y}_{9}$ glasses [11] and with $\mathrm{Fe}_{2} \mathrm{~B}$ and $\mathrm{Fe}_{3} \mathrm{~B}$ observed by Chang et al. in $\mathrm{Fe}_{72} \mathrm{~B}_{2} \mathrm{Y}_{6}$ and $\mathrm{Fe}_{70.56} \mathrm{~B}_{21.56} \mathrm{Nb}_{2} \mathrm{Y}_{5.88}$ glasses [13]. They however differ from others reported in literature, namely (i) $\mathrm{Fe}_{23} \mathrm{~B}_{6}$ in Fe based metallic glasses [1,610] among which metallic glasses with similar compositions as ours [6], (ii) Fe solid solution [7,9,10,12,13], (iii) $\mathrm{NbB}$ [13] or (iv) $\mathrm{Fe}_{14} \mathrm{Y}_{2} \mathrm{~B}$ [14]. Such differences must be linked to both the quenching conditions and the chemical compositions of the metallic glasses.

Besides, as the thermodynamic driving force for crystallization of a glass is high and the atomic mobility low, metastable phases form very often before equilibrium is reached [2325]. XRD analyses of the present metallic glass up to $1400^{\circ} \mathrm{C}$ indeed suggested the formation of the stable $\mathrm{Fe}_{14} \mathrm{BY}_{2}$ phase [5] which would replace the metastable $\mathrm{Fe}_{62} \mathrm{~B}_{14} \mathrm{Y}_{3}$ phase formed at the beginning of crystallization.

\subsection{Crystallization mechanism}

APT data revealed that $\mathrm{B}, \mathrm{Fe}, \mathrm{Nb}$ and $\mathrm{Y}$ are randomly distributed in the quenched state (see Fig. 2 and figure in Supplementary data). There could be some short range order but it cannot be evaluated by this technique. Some fluctuations and heterogeneities of composition have been reported in literature in similar Fe-B glasses [2527] and in Fe- $\mathrm{Nb}-\mathrm{Y}-\mathrm{B}$ quaternary glasses with distinct compositions from ours [7]. Such fluctuations of composition can then affect the nucleation and growth of competing crystalline phases during solidification.

The comparison of crystals sizes after 1 and $15 \mathrm{~min}$ at $667^{\circ} \mathrm{C}$ clearly indicates that the growth kinetic of phase 2 is much faster than that of phase 3 (Figs. 4 and 5). However, the nucleation sequence of the different crystals must be discussed and a schematic representation of two different possible scenari is given in Fig. 8:

(i) Primary crystallization of phase 3 followed by the formation of phase 2 (Fig. 8a). Three points are in favor of this mechanism. First, the small size of B atom may promote its mobility in the glass; second, the formation of $\mathrm{Fe}_{2} \mathrm{~B}$ and $\mathrm{FeB}$ is consistent with their low energy of formation $(-67.4 \mathrm{~kJ} / \mathrm{mol}$ and $-65.8 \mathrm{~kJ} / \mathrm{mol}$ 
respectively at $727^{\circ} \mathrm{C}$, i.e. close to the temperature of current isothermal holding [1719]). Conversely, $\mathrm{Fe}_{62} \mathrm{~B}_{14} \mathrm{Y}_{3}$ is metastable and exhibits an energy of formation of $-34.3 \mathrm{~kJ} / \mathrm{mol}$ at least at $0 \mathrm{~K}$ according to ab initio calculations [2123].

(ii) Formation of phase 2 followed by crystallization of phase 3 (Fig. 8b). Such a scenario would be favored by $\mathrm{Y}$ clusters in the quenched glass and relative high mobility of $\mathrm{Fe}$ atoms. This scenario (ii) seems however less realistic than scenario (i) since $\mathrm{Fe}$ atomic diffusion may be sluggish given the $\mathrm{Fe}$ big atomic size.

When phase 3 starts nucleating (called 3a), it rejects $\mathrm{Y}$ since $\mathrm{Nb}-\mathrm{Y}$ heat mixing is positive [6,7]. However, due to their low atomic mobility in the glassy matrix (related to the large atomic size, $181 \mathrm{pm}$ for $\mathrm{Y}$ [1719]), $\mathrm{Y}$ atoms cannot diffuse far and stay near crystal/amorphous matrix interfaces (Figs. 4 and 5). The resulting local Y enrichment in the amorphous phase combined with the low atomic mobility affect the growth rate of these crystals and they remain nanoscaled. The mobility of phase 3 - glass interface is smaller than atomic diffusion rate, which explains the spherical morphology of phase 3 . But, when phase 3 nucleates and starts growing, it also gives rise to a local Fe enrichment and $\mathrm{B}+\mathrm{Nb}$ depletion in the neighboring amorphous phase. This obviously favors the formation of crystals of phase 2 . Once nucleated, phase 2 exhibits a faster growth kinetic as compared to phase 3 . It is very likely because it is $\mathrm{Fe}$ rich, like the glassy matrix. Besides, composition differences between phase $2\left(\mathrm{Fe}_{62} \mathrm{~B}_{14} \mathrm{Y}_{3}\right)$ and the amorphous matrix give rise to chemical composition gradients. They have a low amplitude and extend over a distance of only $3 \mathrm{~nm}$ at the beginning of crystallization of phase 2 (see intermediate zone in Fig. 4f) and over a much larger length scale after $15 \mathrm{~min}$ at $667^{\circ} \mathrm{C}$ (up to $50 \mathrm{~nm}$, see Fig. 5h). Assuming that the effective diffusion distance of atoms is equal to the radius of phase 2 particles, then an estimate of the minimum atomic diffusion coefficient at $667^{\circ} \mathrm{C}$ would be on the order of $10^{-17} \mathrm{~m}^{2} / \mathrm{s}$ after $1 \mathrm{~min}$ and $10^{-18}$ $\mathrm{m}^{2} / \mathrm{s}$ after $15 \mathrm{~min}$. Finally, the local atomic redistribution at the vicinity of phase 2 promotes the local nucleation of novel crystals of phase 3 (labelled " $3 b$ ") with a composition slightly different from initial crystals of this phase (labelled 3a) (Fig. 5h, Tab. 3). Thus crystals of phase 3 could exhibit different chemical compositions as measured experimentally and displayed in Fig. 9. There is no systematic connection with the particle size, but it simply depends on its location, namely either embedded in the glassy matrix (phase 3a) or close to a crystal of phase 2 (phase $3 \mathrm{~b}$ ). The formation of crystals $3 \mathrm{~b}$ thus leads to a depletion in B and $\mathrm{Nb}$ at the neighborhood of phase 2 . These conditions become once again favorable for the growth of phase 2 .

The growth of cauliflower shaped phase 2 (Figs. $6 \mathrm{f}$ and 5a-c) is very likely due to the chemical gradients and high driving force and the dendritic shape of phase 2 very likely results from growth instabilities; the mobility of phase 2 - glass interface is indeed only slightly smaller than atomic diffusion rate. Actually, the crystallization of a glass is known to be very much slower than conventional solidification of a liquid and the crystal growth is so slow that the transformation can be isothermal with negligible temperature gradients [2426]. In conclusion, phase 3 appears as a catalyst of phase 2 nucleation and growth, and conversely.

Among the 4 phase transformations, namely polymorphous, primary, eutectic and spinodal, which can occur at the devitrification of the glassy alloys [24,2626,28] and according to our current results, the $\mathrm{Fe}_{64} \mathrm{~B}_{24} \mathrm{Y}_{4} \mathrm{Nb}_{6} \mathrm{Al}_{0.4}$ metallic glass experienced primary crystallizations. 


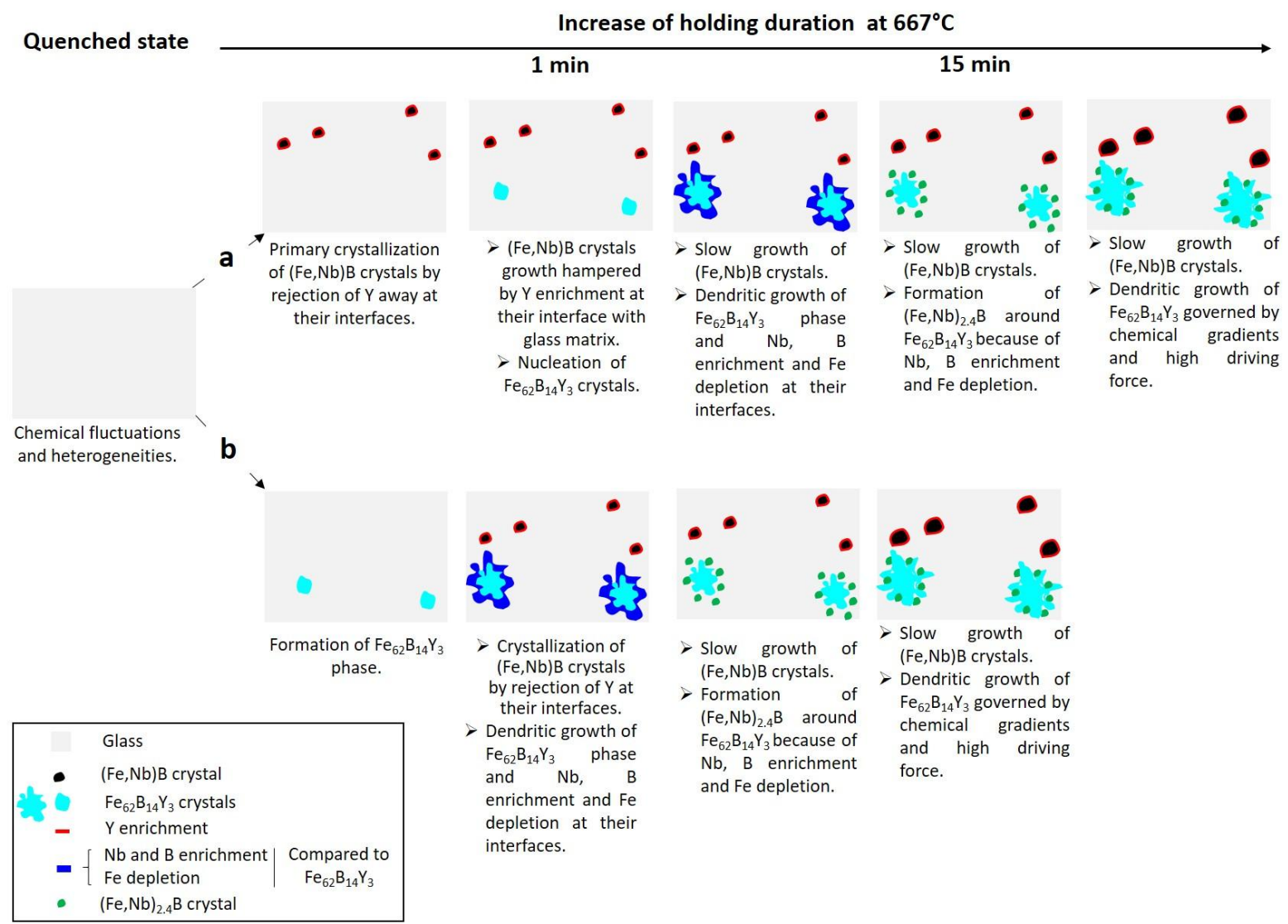

Figure 8: Schematics of the first steps of crystallization in the $\mathrm{Fe}_{64} \mathrm{~B}_{24} \mathrm{Y}_{4} \mathrm{Nb}_{6} \mathrm{Al}_{0.4}$ metallic glass during isothermal holding at $667^{\circ} \mathrm{C}$.

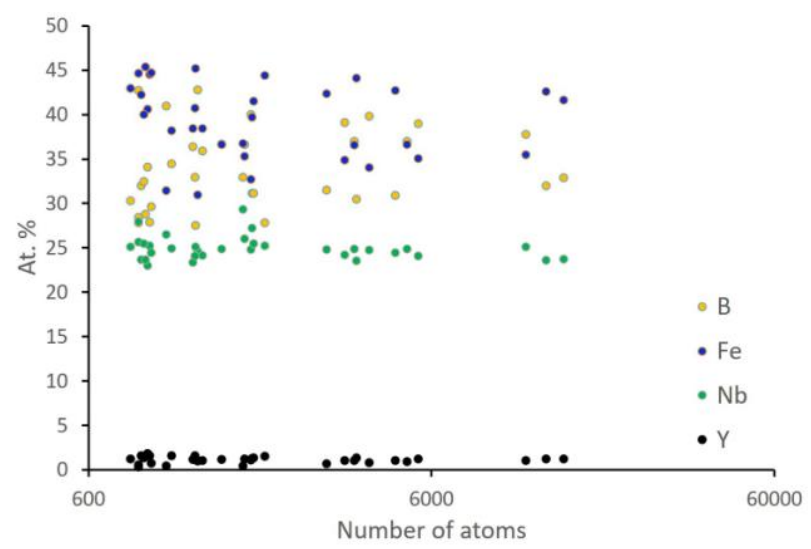

Figure 9: Chemical composition of crystals of phase $3 v s$. size (number of atoms detected in the particle) in the sample after a 15 min holding treatment at $667^{\circ} \mathrm{C}$ (APT analyses).

\section{Conclusions}

The early stages of crystallization in a $\mathrm{Fe}_{64} \mathrm{~B}_{24} \mathrm{Y}_{4} \mathrm{Nb}_{6} \mathrm{Al}_{0.4}$ metallic glass after various holding durations at $667^{\circ} \mathrm{C}$ were analyzed at the atomic scale by using complementary devices, namely APT, HRTEM and XRD. This study enabled to unveil the mechanism of crystallization in such a metallic glass:

1) some $(\mathrm{Fe}, \mathrm{Nb}) \mathrm{B}$ crystals nucleate first by rejecting $\mathrm{Y}$ at their interface with the glassy matrix, which hinders their growth,

2) then crystals with the $\mathrm{Fe}_{62} \mathrm{~B}_{14} \mathrm{Y}_{3}$ stoichiometry nucleate, 
3) the $\mathrm{B}$ and $\mathrm{Nb}$ enrichment and $\mathrm{Fe}$ depletion close to the $\mathrm{Fe}_{62} \mathrm{~B}_{14} \mathrm{Y}_{3}$ crystals promote the nucleation of $(\mathrm{Fe}, \mathrm{Nb})_{2.4} \mathrm{~B}$ phase,

4) the chemical gradients resulting from the formation of $\mathrm{Fe}_{62} \mathrm{~B}_{14} \mathrm{Y}_{3}$ crystals and the high driving force favor dendritic growth of the latter crystals.

\section{Appendix}

Table A: Comparison of chemical composition of phases 1, 2 and 3 and of phases reported in literature.

\begin{tabular}{|c|c|c|c|c|c|c|c|}
\hline Atomic ratio & $\mathrm{Fe} / \mathrm{B}$ & $\mathrm{Fe} / \mathrm{Y}$ & $\mathrm{Fe} / \mathrm{Nb}$ & $\mathrm{B} / \mathrm{Y}$ & $(\mathrm{Fe}+\mathrm{Nb}) / \mathrm{B}$ & $\mathrm{B} / \mathrm{Nb}$ & Reference \\
\hline Phase $1(1 \mathrm{~min})$ & 2.96 & 16.7 & 9.47 & 5.56 & & & \multirow[t]{4}{*}{ Present work } \\
\hline Phase 1 (15 min) & 2.60 & 17.83 & 12.65 & 6.84 & & & \\
\hline Phase $2(1 \mathrm{~min})$ & $9.7-10.3$ & $12.75-16.1$ & & 1.2-1.7 & & & \\
\hline Phase $2(15 \mathrm{~min})$ & 7.6 & 26.2 & & 3.4 & & & \\
\hline $\mathrm{Fe}_{62} \mathrm{~B}_{14} \mathrm{Y}_{3}$ & 4.4 & 20.6 & - & 4.7 & & - & \multirow[t]{23}{*}[21-2223,24]{} \\
\hline $\mathrm{Fe}_{23} \mathrm{~B}_{3} \mathrm{Y}_{2}$ & 7.7 & 11.5 & - & 1.5 & & - & \\
\hline $\mathrm{Fe}_{2} \mathrm{~B}_{2} \mathrm{Y}$ & 1.0 & 2.0 & - & 2.0 & & - & \\
\hline $\mathrm{Fe}_{24} \mathrm{~B}_{2} \mathrm{Y}_{2}$ & 12 & 12 & - & 1.0 & & - & \\
\hline $\mathrm{Fe}_{34} \mathrm{~B}_{5} \mathrm{Y}_{2}$ & 6.8 & 17.0 & - & 2.5 & & - & \\
\hline $\mathrm{FeB}_{7} \mathrm{Y}_{3}$ & 0.14 & 0.3 & - & 2.3 & & - & \\
\hline $\mathrm{Fe}_{44} \mathrm{~B}_{8} \mathrm{Y}_{4}$ & 5.5 & 11.0 & - & 2.0 & & - & \\
\hline $\mathrm{Fe}_{51} \mathrm{~B}_{9} \mathrm{Y}_{6}$ & 5.7 & 8.5 & - & 1.5 & & - & \\
\hline $\mathrm{Fe}_{14} \mathrm{BY}_{2}$ & 14 & 7 & - & 0.5 & & - & \\
\hline $\mathrm{Fe}_{6} \mathrm{~B}_{18} \mathrm{Y}_{15}$ & 0.33 & 0.4 & - & 1.2 & & - & \\
\hline $\mathrm{Fe}_{8} \mathrm{~B}_{8} \mathrm{Y}_{2}$ & 1 & 4 & - & 4 & & - & \\
\hline $\mathrm{Fe}_{8} \mathrm{~B}_{2} \mathrm{Y}_{2}$ & 4 & 4 & - & 1 & & - & \\
\hline $\mathrm{Fe}_{4} \mathrm{~B}_{24} \mathrm{Y}_{8}$ & 0.17 & 0.5 & - & 3 & & - & \\
\hline $\mathrm{Fe}_{4} \mathrm{~B}_{16} \mathrm{Y}_{4}$ & 0.25 & 1 & - & 4 & & - & \\
\hline $\mathrm{Fe}_{4} \mathrm{~B}_{28} \mathrm{Y}_{12}$ & 0.14 & 0.33 & - & 2.33 & & - & \\
\hline $\mathrm{Fe}_{13} \mathrm{~B}_{2} \mathrm{Y}_{3}$ & 6.5 & 4.33 & - & 0.67 & & - & \\
\hline $\mathrm{Fe}_{27} \mathrm{~B}_{18} \mathrm{Y}_{9}$ & 1.5 & 3 & - & 2 & & - & \\
\hline $\mathrm{Fe}_{84} \mathrm{~B}_{24} \mathrm{Y}_{8}$ & 3.5 & 10.5 & - & 3 & & - & \\
\hline $\mathrm{Fe}_{6} \mathrm{~B}_{12} \mathrm{Y}_{4}$ & 0.5 & 1.5 & - & 3 & & - & \\
\hline $\mathrm{Fe}_{9} \mathrm{~B}_{18} \mathrm{Y}_{12}$ & 0.5 & 0.75 & - & 1.5 & & - & \\
\hline $\mathrm{Fe}_{10} \mathrm{~B}_{8} \mathrm{Y}_{4}$ & 1.25 & 2.5 & - & 2 & & - & \\
\hline $\mathrm{Fe}_{11} \mathrm{~B}_{4} \mathrm{Y}_{1}$ & 2.75 & 11 & - & 4 & & - & \\
\hline $\mathrm{Fe}_{6} \mathrm{~B}_{8} \mathrm{Y}_{2}$ & 0.75 & 3 & - & 4 & & - & \\
\hline Phase 3a (1 min) & 0.76 & - & 1.75 & - & 1.195 & 2.3 & \multirow[t]{3}{*}{ Present work } \\
\hline Phase 3a (15 min) & 0.74 & - & 1.47 & - & 1.25 & 1.97 & \\
\hline Phase 3b (15 min) & 1.57 & - & 1.91 & - & 2.39 & 1.21 & \\
\hline $\mathrm{FeBNb}$ & 1 & - & 1 & - & 2 & 1 & \multirow[t]{5}{*}{ [2830] } \\
\hline $\mathrm{FeB}_{2} \mathrm{Nb}_{2}$ & 0.5 & - & 0.5 & - & 1.5 & 1 & \\
\hline $\mathrm{FeB}_{7} \mathrm{Nb}_{3}$ & 0.14 & - & 0.33 & - & 0.57 & 2.33 & \\
\hline $\mathrm{Fe}_{2} \mathrm{~B}_{4} \mathrm{Nb}_{4}$ & 0.5 & - & 0.5 & - & 1.5 & 1 & \\
\hline $\mathrm{Fe}_{3} \mathrm{~B}_{4} \mathrm{Nb}_{3}$ & 0.75 & - & 1 & - & 1.5 & 1.33 & \\
\hline $\mathrm{Fe}_{3} \mathrm{~B}_{8} \mathrm{Nb}_{7}$ & 0.375 & - & 0.43 & - & 1.25 & 1.14 & {$[5,2729]$} \\
\hline $\mathrm{Fe}_{4} \mathrm{~B}_{2} \mathrm{Nb}_{4}$ & 2 & - & 1 & - & 4 & 0.5 & \multirow[t]{13}{*}{ [2830] } \\
\hline $\mathrm{Fe}_{4} \mathrm{~B}_{4} \mathrm{Nb}_{2}$ & 1 & - & 2 & - & 1.5 & 2 & \\
\hline $\mathrm{Fe}_{4} \mathrm{~B}_{16} \mathrm{Nb}_{4}$ & 0.25 & - & 1 & - & 0.5 & 4 & \\
\hline $\mathrm{Fe}_{6} \mathrm{~B}_{8} \mathrm{Nb}_{15}$ & 0.75 & - & 0.4 & - & 2.625 & 0.53 & \\
\hline $\mathrm{Fe}_{8} \mathrm{~B}_{8} \mathrm{Nb}_{2}$ & 1 & - & 4 & - & 1.25 & 4 & \\
\hline $\mathrm{Fe}_{10.66} \mathrm{~B}_{3} \mathrm{Nb}_{0.84}$ & 3.5 & - & 12.6 & - & 3.83 & 3.57 & \\
\hline $\mathrm{Fe}_{22} \mathrm{~B}_{10} \mathrm{Nb}_{12}$ & 2.2 & - & 1.83 & - & 3.4 & 0.83 & \\
\hline $\mathrm{Fe}_{27} \mathrm{~B}_{18} \mathrm{Nb}_{9}$ & 1.5 & - & 3 & - & 2 & 2 & \\
\hline $\mathrm{Fe}_{56} \mathrm{~B}_{4} \mathrm{Nb}_{8}$ & 14 & - & 7 & - & 16 & 0.5 & \\
\hline $\mathrm{FeB}$ & 1 & - & - & - & 1 & - & \\
\hline $\mathrm{Fe}_{2} \mathrm{~B}$ & 2 & - & - & - & 2 & - & \\
\hline $\mathrm{Fe}_{3} \mathrm{~B}$ & 3 & - & - & - & 3 & - & \\
\hline $\mathrm{Fe}_{23} \mathrm{~B}_{6}$ & 3.83 & - & - & - & 3.83 & - & \\
\hline
\end{tabular}

\section{Aknowledgments}


The authors are very thankful to Wei Jiang from Hefei University of Technology, China for the provision of the samples and Florent Blanchard, UCCS, Lille University, France for having performed the X-ray diffraction experiments. The authors acknowledge financial support from the CNRS-CEA "METSA" French network (FR CNRS 3095 «IRMA ») on the platform GPM (Rouen). Fabien Cuvilly is gratefully acknowledged for the APT sample preparation.

The TEM facility in Lille (France) is supported by the Conseil Régional du Nord-Pas de Calais, and the European Regional Development Fund (ERDF).

\section{References}

[1] C. Suryanarayana, A. Inoue, Iron-based bulk metallic glasses, Int. Mat. Rev. 5(3) (2013) 131-166. https://doi.org/10.1179/1743280412Y.0000000007.

[2] H.X. Li, Z.C. Lu, S.L. Wang, Y. Wu, Z.P. Lu, Fe-based bulk metallic glasses: Glass formation, fabrication, properties and applications, Prog. Mater. Sci. 103 (2019) 235-318. https://doi.org/10.1016/j.pmatsci.2019.01.003.

[3] A. Fillon, X. Sauvage, B. Lawrence, C. Sinclair, M. Perez, A. Week, E. Cantergiani, T. Epicier, C.P. Scott, On the direct nucleation and growth of ferrite and cementite without austenite. Scr. Mat. 95 (2015) 35-38. https://doi.org/10.1016/j.scriptamat.2014.09.025.

[4] M.T. Clavaguera-Mora, N. Clavaguera, D. Crespo, T. Pradell, Crystallization kinetics and microstructure development in metallic systems. Prog. Mater. Sci. 47 (2002) 559-619. https://doi.org/10.1016/S0079-6425(00)00021-9.

[5] M.-N. Avettand-Fènoël, M. Marinova, R. Taillard, W. Jiang, Thermal stability, phase transformations and mechanical properties of a Fe64B24Y4Nb6 metallic glass, J. All. Compds. 854 (2021) 157068. https://doi.org/10.1016/j.jallcom.2020.157068.

[6] S. Lee, H. Kato, T. Kubota, K. Yubuta, A. Makino, A. Inoue, Excellent thermal stability and bulk glass forming ability of Fe-B-Nb-Y soft magnetic metallic glass, Mater. Trans. 49(3) (2008) 506-512. https://doi.org/10.2320/matertrans.MBW200732.

[7] Q. Yu, X.D. Wang, H.B. Lou, Q.P. Cao, J.Z. Jiang, Atomic packing in Fe-based metallic glasses, Acta Mater. 102 (2016) 116-124. DOI:10.1016/J.ACTAMAT.2015.09.001.

[8] C.C. Yuan, C. Deng, H.P. Zhang, M.Z. Li, B.L. Shen, Ab initio simulations of the atomic and electronic environment around B in Fe-Nb-B metallic glasses, Intermetallics 112 (2019) 106501. https://doi.org/10.1016/j.intermet.2019.106501.

[9] X.M. Huang, X.D. Wang, J.Z. Jiang, Origin of high glass forming ability of Y containing Fe-B based alloys, J. All. Compds. 485 (2009) L35-L38. https://doi.org/10.1016/j.jallcom.2009.06.049.

[10] A. Hirata, Y. Hirotsu, K. Amiya, N. Nishiyama, A. Inoue, Fe23B6 type quasicrystallike structures without icosahedral atomic arrangement in an Fe-based metallic glass, Phys. Rev. B 80 (2009)140201. DOI: 10.1103/PhysRevB.80.140201. 
[11] D.B. de Mooij, J.L.C. Daams, K.H.J. Buschow, A metastable compound in the Y-B-Fe system. Philips J. Res. 42(3) (1987) 339-349

[12] D.S. Song, J.H. Kim, E. Fleury, W.T. Kim, D.H. Kim, Synthesis of ferromagnetic Febased bulk glassy alloys in the Fe-Nb-B-Y system, J. All. Compds. 389 (2005) 159-164. https://doi.org/10.1016/j.jallcom.2004.08.014.

[13] H.W. Chang, Y.C. Huang, C.W. Chang, C.C. Hsieh, W.C. Chang, Soft magnetic properties and glass formability of Y-Fe-B-M bulk metals (M=Al, Hf, Nb, Ta and Ti), J. All. Compds. 472 (2009) 166-170. https://doi.org/10.1016/j.jallcom.2008.05.014.

[14] M.K. Miller, C.T. Liu, J.A. Wright, W. Tang, K. Hildal, APT characterization of some iron-based bulk metallic glasses, Intermetallics 14 (2006) 1019-1026.

https://doi.org/10.1016/j.intermet.2006.01.040.

[15] P. Rezaei-Shahreza, A. Seifoddini, S. Hasani, Z. Jaafari, A. Sliwa, M. Nabialek, Isokinetic analysis of $\mathrm{Fe}_{41} \mathrm{Co}_{7} \mathrm{Cr}_{15} \mathrm{Mo}_{14} \mathrm{Y}_{2} \mathrm{C}_{15} \mathrm{~B}_{6}$ bulk metallic glass: effect of minor copper addition, Materials 13, 3704 (2020) 1-18. https://doi:10.3390/ma13173704

[16] S. Hasani, P. Rezaei-Shahreza, A. Seifoddini, The effect of $\mathrm{Cu}$ minor addition on the non-isothermal kinetic of nano-crystallites formation in $\mathrm{Fe}_{41} \mathrm{Co}_{7} \mathrm{Cr}_{15} \mathrm{Mo}_{14} \mathrm{Y}_{2} \mathrm{C}_{15} \mathrm{~B}_{6} \mathrm{BMG}, \mathrm{J}$. Therm. Anal. Calorim. 143 (2021) 3365-3375. https://doi.org/10.1007/s10973-020-09716-6

[1517] M.J. Duarte, A. Kostka, J.A. Jimenez, P. Choi, J. Klemm, D. Crespo, D. Raabe, F.U. Renner, Crystallization, phase evolution and corrosion of Fe-based metallic glasses: An atomic-scale structural and chemical characterization study, Acta Mater. 71 (2014) 20-30. https://doi.org/10.1016/j.actamat.2014.02.027.

[1618] J. Barthel, Dr. Probe: A software for high-resolution STEM image simulation. Ultramicroscopy 193 (2018) 1-11. https://doi.org/10.1016/j.ultramic.2018.06.003.

[1719] E.A. Brandes, G.B. Brook, Smithells Metals Reference Book, $7^{\text {th }}$ ed., Elsevier, Oxford, 1992.

[1820] X.M. Huang, X.D. Wang, Y. He, Q.P. Cao, J.Z. Jiang, Are there two glass transitions in Fe-M-Y-B (M=Mo, W, Nb) bulk metallic glasses? Scr. Mater. 60 (2009) 152-155. https://doi.org/10.1016/j.scriptamat.2008.09.022.

[1921] X.M. Huang, C.T. Chang, Z.Y. Chang, X.D. Wang, Q.P. Cao, B.L. Shen, A. Inoue, J.Z. Jiang, Formation of bulk metallic glasses in the Fe-M-Y-B (M=transition metal) system, J. All. Compds. 460 (2008) 708-713. DOI:10.1016/J.JALLCOM.2007.09.063.

[2022] I. Kaban, P. Jovari, A. Waske, M. stoica, J. Bednarcik, B. Beuneu, N. Mattern, J. Eckert, Atomic structure and magnetic properties of Fe-Nb-B metallic glasses, J. All. Compds. 586 (2014) S189-S193. https://doi.org/10.1016/j.jallcom.2012.09.008.

[2123] M. Mihalkovic, M. Widom, Ab initio calculations of cohesive energies of Fe-based glass-forming alloys, Phys. Rev. B 70 (2004) 144107. DOI: 10.1103/PhysRevB.70.144107. 
[2224] Alloy data base. http://alloy.phys.cmu.edu/, 2021 (accessed 15 ${ }^{\text {th }}$ February 2021) and Crystallography open data base. http://qiserver.ugr.es/cod/search.html, 2021 (accessed 15 February 2021).

[2325] M. Mihalkovic, M. Widom, Cohesive energies of Fe-based glass-forming alloys, (2004) arXiv:cond-mat/0405298.

[2426] A.L. Greer, Metallic Glasses, in D.E. Laughlin, K. Hono (Eds.), Physical Metallurgy, $5^{\text {th }}$ edition. Elsevier, New York, 2014, pp. 305-385. https://doi.org/10.1016/B978-0-44453770-6.00004-6.

[2527] D.H. Kim, W.T. Kim, E.S. Park, N. Mattern, J. Eckert, Phase separation in metallic glasses, Prog. Mater. Sci. 58 (2013) 1103-1172. DOI: 10.1016/j.pmatsci.2013.04.002.

[2628] D.V. Louzguine-Luzgin, Vitrification and devitrification processes in metallic glasses. J. All. Compds. 586 (2014) S2-S8. https://doi.org/10.1016/j.jallcom.2012.09.057.

[2729] Q. Zheng, R. Gumeniuk, H. Borrmann, W. Schnelle, A.A. Tsirlin, H. Rosner, U. Burkhardt, M. Reissner, Y. Grin, A. Leithe-Jasper, Ternary borides Nb7Fe3B8 and Ta7Fe3B8 with Kagome-type iron framework, Dalton Transactions 45(23) (2016). DOI: $\underline{10.1039 / C 6 D T 01164 K}$.

[2830] V. Raghavan, The B-Fe-Nb (Boron - iron - Niobium) System, in V. Raghavan, G.V. Raynor, V.G. Rivlin (Eds.), Phase diagrams of ternary Iron Alloys, Part 6B, Monograph Series on Alloy Phase Diagram, Indian Institute of Metals, Calcutta, 1992, pp. 370-373. 


\section{Supplementary data S1}

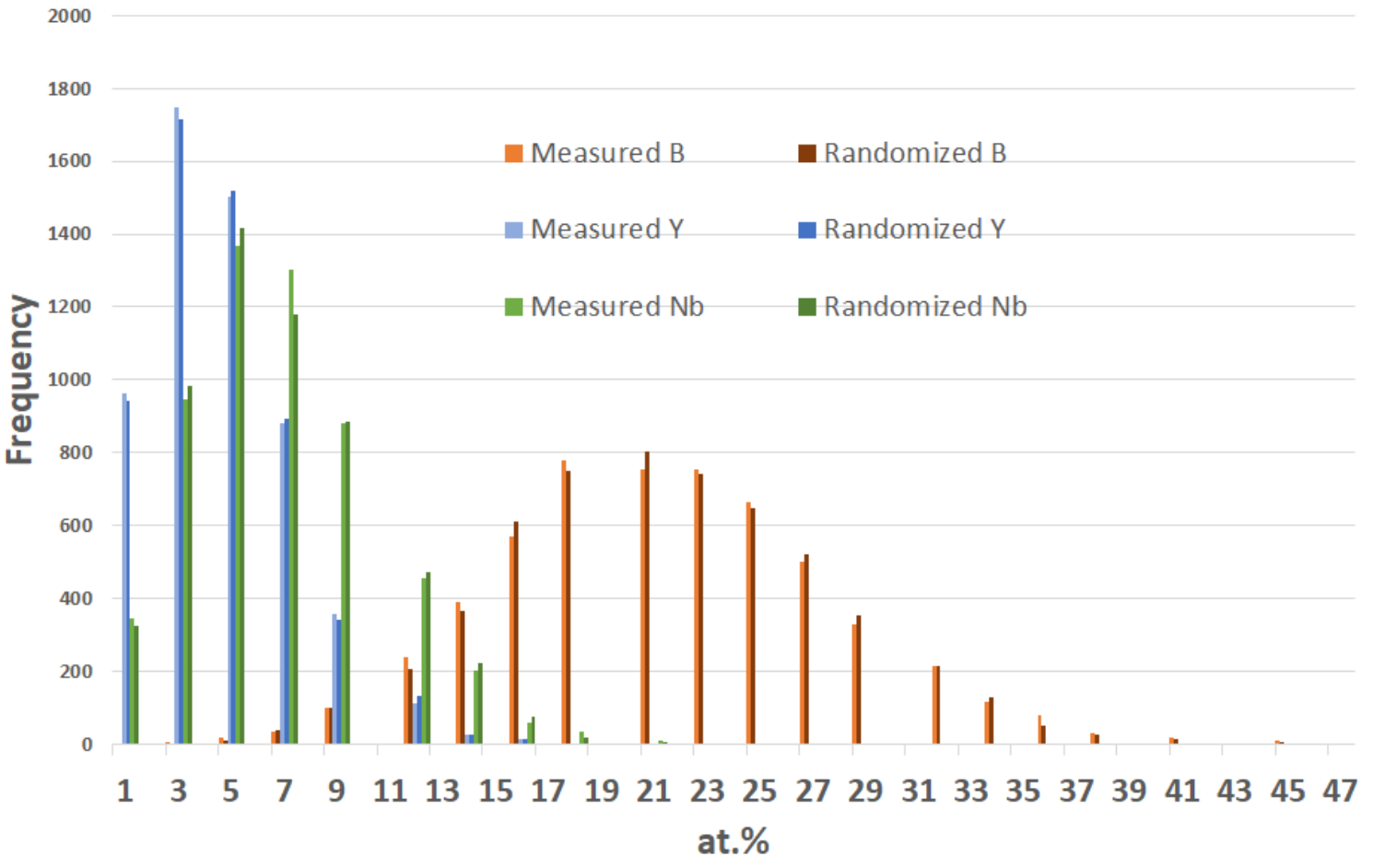

S1: Frequency distribution histograms showing the distribution of the $\mathrm{B}, \mathrm{Nb}$ and $\mathrm{Y}$ concentrations measured in $1 \times 1 \times 1 \mathrm{~nm}^{3}$ sampling volumes in an APT data set collected in the as quenched state of the metallic glass. Real data ("Measured") are compared to distributions calculated after a full randomization ("Randomized") of the nature of each atom. It clearly shows that the as-quenched state exhibits a homogeneous distribution of elements. 